University of Nebraska - Lincoln

DigitalCommons@University of Nebraska - Lincoln

Faculty Publications, Classics and Religious

Studies Department

2006

\title{
Reburying the Treasure-Maintaining the Continuity: Two Texts by Śākya Mchog Ldan on the Buddha-Essence
}

Yaroslav Komarovski

University of Nebraska-Lincoln, ykomarovski2@unl.edu

Follow this and additional works at: https://digitalcommons.unl.edu/classicsfacpub

Part of the Ancient Philosophy Commons, Comparative Literature Commons, Metaphysics Commons, Other Classics Commons, and the South and Southeast Asian Languages and Societies Commons

Komarovski, Yaroslav, "Reburying the Treasure-Maintaining the Continuity: Two Texts by Śākya Mchog Ldan on the Buddha-Essence" (2006). Faculty Publications, Classics and Religious Studies Department. 79.

https://digitalcommons.unl.edu/classicsfacpub/79

This Article is brought to you for free and open access by the Classics and Religious Studies at DigitalCommons@University of Nebraska - Lincoln. It has been accepted for inclusion in Faculty Publications, Classics and Religious Studies Department by an authorized administrator of DigitalCommons@University of Nebraska - Lincoln. 
Published in Journal of Indian Philosophy 34 (2006), pp. 521-570;

doi: 10.1007/s10781-006-9004-2 Copyright (c) 2007 Springer Science+Business Media B.V. Used by permission.

Submitted November 13, 2006; accepted November 27, 2006; published online February 2, 2007.

\title{
Reburying the Treasure-Maintaining the Continuity: Two Texts by Śākya Mchog Ldan on the Buddha-Essence
}

\author{
Yaroslav Komarovski \\ Department of Religious Studies, University of Virginia
}

\begin{abstract}
The rich and interconnected universe of Śākya Mchog Ldan's views, including those on the buddha-essence, cannot be limited to or summarized in a few neat categories. Nevertheless, the following two interrelated ideas are crucial for understanding Śakya Mchog Ldan's interpretation of the buddha-essence:

1) only Mahāyāna āryas ('phags pa) have the buddha-essence characterized by the purity from adventitious stains (glo bur rnam dag);

2 ) the buddha-essence is inseparable from the positive qualities (yon tan, guna) of a buddha;
\end{abstract}

In his writings, Śākya Mchog Ldan argues against identifying the buddhaessence as a mere natural purity (rang bzhin rnam dag), i.e., the state of natural freedom from obscurations as it is taught in the Middle or Second Wheel of Doctrine (chos 'khor, dharmacakra) and its commentaries. The buddha-essence has to be posited as inseparability from positive qualities of a buddha.

Śākya Mchog Ldan approaches the buddha-essence inseparable from positive qualities of a buddha in two ways. In some texts, such as the Essence of Sütras and Tantras, he argues that it has to be identified only as purity from adventitious stains, i.e., the removal of all or some negative qualities that prevent one from directly seeing the buddha-essence. In other texts, such as The Sun Unseen Before, he interprets it as the purity from adventitious stains and the natural purity as it is taught in some sūtras of the Third Wheel of Doctrine and their commentaries. That type of natural purity is understood as the state of natural freedom from all obscurations insepara- 
ble from positive qualities of a buddha. Thereby, in this second type of texts, Śākya Mchog Ldan arrives at positing two types of the buddha-essence: relative (kun rdzob, samvrti) and ultimate (don dam, paramārtha). Despite different interpretations of the natural purity, the identification of the buddhaessence as the purity from adventitious stains is present in both.

In his interpretation of the buddha-essence, Śākya Mchog Ldan utilizes the categories of the three levels found in the Sublime Continuum: the impure (ma dag, aśuddha), impure-pure (ma dag dag pa, aśuddhaśuddha, i.e. partially pure) and very pure (shin tu rnam dag, suviśuddha) levels that correspond respectively to the categories of sentient beings, bodhisattvas (understood as ārya bodhisattvas in this context), and tathāgatas. Śākya Mchog Ldan argues that one becomes a possessor of the buddha-essence free from adventitious stains only on the impure-pure level. In other words, when bodhisattvas enter the Mahāyāna Path of Seeing (mthong lam, darśanamārga) simultaneously with the attainment of the first boddhisattva ground (byang chub sems pa'i sa, bodhisattavabhūmi) of Utmost Joy (rab tu dga' ba, pramuditā), they become āryas, i.e. "exalted" or "superior," bodhisattvas, directly realize the ultimate truth (don dam bden pa, paramärthasatya), and thereby for the first time generate an antidote to obscurations of knowables (shes bya'i sgrib pa, jñeyāvarana). They start gradually removing them, and thereby actually see at least a partial purification of stains "covering" the buddha-essence, and its inseparability from at least some positive qualities. Such is not possible for anyone below that level, even for the non-Mahāyāna arhats (i.e., śrāvakas and pratyekabuddhas). Thus, only Mahāyāna āryas have the buddha-essence characterized by the purity from adventitious stains; āryabodhisattvas have only a part of it, while buddhas have it completely.

Keywords: Buddha-nature, Buddhist philosophy, Buddhism, Tibetan Buddhism, Madhyamaka, Other-emptiness views, Less known/alternative Buddhist theories on reality, Buddhist theories of cognition, Buddhist tantric views, 15th Century Tibetan Buddhist thought

\section{Introduction}

In this paper, I am introducing the views of the fifteenth century Tibetan Buddhist thinker Śākya Mchog Ldan (1428-1507) on the buddha-essence (sangs rgyas kyi snying po, buddhagarbha), which he also interchangeably calls "sugata-essence" (bde gshegs snying po, sugatagarbha), and "tathāgataessence" (de bshin gshegs pa'i snying po, tathāgatagarbha).

My objective is to show how Śākya Mchog Ldan retained distinguishing elements of his view of the non-tantric version of the buddhaessence $^{1}$ in two otherwise quite different texts and contexts, around the period when his own unique views on the Mahayana tenets be-

1 Śakya Mchog interprets the tantric and non-tantric types of the tathāgata-essence differently. See below. 
gan to crystallize, and later. ${ }^{2}$ I am concentrating on two texts: the Essence of Sütras and Tantras: Explanation of the Buddha-essence ${ }^{3}$ and The Sun Unseen Before: the Definitive Meaning of the "Sublime Continuum" Treatise. ${ }^{4}$ Both texts focus exclusively on the buddha-essence, and address other topics only in order to clarify it. The first text was written in 1474, before the second one. ${ }^{5}$ The Essence of Sütras and Tantras addresses several interpretations of the buddha-essence, but treats in most detail the ideas contained in Maitreya's Sublime Continuum ${ }^{6}$ and its

2 Śākya Mchog Ldan started explicitly questioning-though not necessarily in the sense of disagreeing with-the views expressed in the authoritative text by Sa Skya Pandita Kun Dga' Rgyal Mtshan (1182-1251), Clear Differentiation of the Three Codes (Sdom pa gsum gyi rab tu dbye ba, Sa skya bka' 'bum, vol. 12 (na), 1a-48b), in 1475, when he wrote Good Questions about the "Clear Differentiation of the Three Codes" (Sdom gsum rab dbye la dri ba legs pa), Collected Works, vol. 17, 448-462 (Thimphu, Bhutan: Kunzang Tobgyey, 1975). In 1481, he answered his own questions in the Golden Spoon: A Resolved Abundant Discourse on the "Clear Differentiation of the Three Codes" Treatise (Sdom gsum gyi rab tu dbye ba'i bstan bcos kyi 'bel gtam rnam par nges pa legs bshad gser gyi thur ma), Collected Works, vols. 6-7 (Thimphu, Bhutan: Kunzang Tobgyey, 1975; hereafter, Golden Spoon). It is impossible to point out the end of this "crystallization period" because, until his death in 1507, Śākya Mchog Ldan kept polishing and updating his views, including those on the buddha-essence. But Śăkya Mchog Ldan had already well organized his own unique views on the nature of the Mahāyāna tenets at least by 1489, when he wrote the Rain of Ambrosia: Extensive [Auto-] Commentary on the "Profound Thunder amidst the Clouds of the Ocean of Definitive Meaning" (Nges don rgya mtsho sprin gyi 'brug sgra zab mo'i rgyas 'grel bdud rtsi'i char 'bebs), vol. 2, which I am currently translating. (Because all the works of Śākya Mchog Ldan that I am dealing with are contained in his collected works in 24 volumes, for the titles addressed below I will be providing only volume numbers, and page numbers when necessary.)

3 Sangs rgyas kyi snying po'i rnam bshad mdo rgyud snying po, vol. 13, 124-136. (Hereafter, Essence of Sütras and Tantras.)

4 Rgyud bla ma'i bstan bcos kyi nges don sngon med nyi ma, vol. 13, 113-124. (Hereafter, The Sun Unseen Before.)

5 No date of composition of The Sun Unseen Before is provided, although we learn from the colophon that the text was requested by Dge 'dun dpal, the same person by whose request Śākya Mchog Ldan wrote the Seventeen Wondrous Answers to The Questions of the Whole Monastic Community of Gzi Bsam 'Grub Gling (Gzi bsam 'grub gling pa'i dge 'dun spyi'i dris lan ya mtshan bcu bdun pa; hereafter Seventeen Wondrous Answers), vol. $23,418-473$, very late in his life, in 1503. It is evident that The Sun Unseen Before is of a later date than the Essence of Sütras and Tantras because in The Sun Unseen Before, Śākya Mchog Ldan presents False Aspectarian (rnam rdzun pa, al īkākāra) Yogācārins as Mādhyamikas, and calls them "False Aspectarian Mādhyamikas" (Rnam rdzun dbu ma $p a, * a l$ ìkākäramādhyamika) as the matter of fact. Such terminology Śākya Mchog Ldan applies only in relatively late texts, written no earlier than 1477, when he composed the Ocean of Scriptural Statements and Reasoning: Treasury of Ascertainment of Mahāyāna Madhyamaka (Theg pa chen po dbu ma rnam par nges pa'i bang mdzod lung dang rigs pa'i rgya mtsho), vol. 14-15, in which he started classifying False Aspectarian (rnam rdzun pa, al īkākāra) Yogācāra as a subdivision of Madhyamaka. The Essence of Sūtras and Tantras, on the other hand, was written just a month before Śākya Mchog Ldan composed another text: the Drumming Sounds of Melodious Voice of Brahma: Refutation of Mistakes About Meditative Stages of the Great Middle and Explanation of the Tenets and Topics of the Views of Consequentialists and Autonomists (Dbu ma chen po'i sgom rim la 'khrul pa spong shing thal rang gi grub pa'i mtha' dang lta ba'i gnas rnam par bshad pa tshangs pa'i dbyangs kyi rnga sgra), vol. 4 , in which he still counted False Aspectarian views as those of Cittamātra (305-306, 340-341). See note 41 and The Sun Unseen Before, 120-121, for more details.

6 Sublime Continuum of Mahāyāna (Mahāyānottaratantraśāstra, Theg pa chen po rgyud bla ma). D4024, sems tsam, phi, 54b-73a. (Hereafter, Sublime Continuum.) 
commentary by Asanga. ${ }^{7}$ The Sun Unseen Before limits itself almost exclusively to the buddha-essence presented in Maitreya's Sublime Continuum. At the same time, rather than focusing on specific topics of the Sublime Continuum-as the first text does-it addresses the buddha-essence from the broader perspective of the relative (kun rdzob, samvrti) and ultimate (don dam, paramārtha) levels, and their relationship. As Śākya Mchog Ldan himself states at the end of The Sun Unseen Before, his interpretation is unique, and was never given before by any Tibetan thinker.

Both the Essence of Sūtras and Tantras and The Sun Unseen Before are translated in their entirety at the end of this paper. My explanations, nonetheless, are not intended as detailed commentaries on the two texts. Rather, focusing on Śākya Mchog Ldan's interpretation of the buddhaessence taught in Maitreya's Sublime Continuum with Asanga's Explanation, I am trying to "fish out" distinguishing characteristics of Śākya Mchog Ldan's view of the buddha-essence in order to demonstrate persistence of this view in the two texts despite their dramatically different approach.

Characteristic elements of Śākya Mchog Ldan's view of the buddha-essence expressed in the two texts are dealt with in more than twenty other texts he composed from the beginning of the "crystallization period" mentioned above until the very end of his life. ${ }^{8}$ I used the bank of these writings as an aid in clarifying Sākya Mchog Ldan's ideas discussed in the two texts.

\section{Distinguishing features of Śākya Mchog Ldan's view of the Buddha-essence in non-tantric texts}

The rich and interconnected universe of Śākya Mchog Ldan's views, including those on the buddha-essence, cannot be limited to or summarized in a few neat categories. Nevertheless, the following two interrelated ideas are crucial for understanding Śākya Mchog Ldan’s interpretation of the buddha-essence:

(1) only Mahāyāna āryas ('phags pa) have the buddha-essence characterized by the purity from adventitious stains (glo bur rnam dag);

(2) the buddha-essence is inseparable from the positive qualities (yon tan, guṇa) of a buddha;

7 Explanation of [Maitreya's] "Sublime Continuum of Mahāyāna" (Mahāyānottaratantraśāstravyākhyā, Theg pa chen po'i rgyud bla ma'i bstan bcos kyi rnam par bshad pa). D4025, sems tsam, phi, 74b-129a. (Hereafter, Explanation.) Śākya Mchog Ldan follows the Tibetan tradition of treating the root text of the Sublime Continuum and its commentary as being composed by two different, albeit related, authors.

8 I provide the list of these works at the end of the paper. They can be grouped into four groups: commentaries on Indian texts (text numbers 1, 3, 4, 6, 7, 8 on the list); writings summarizing essentials of particular topics or the whole body of texts $(2,5,9$ $13,15-16,20)$; letters of replies to particular questions, qualms, and objections raised by different Tibetan thinkers regarding Śākya Mchog Ldan's writings (14, 19, 21-24); descriptions of realizations (rtogs brjod, avadāna) of Indian masters $(17,18)$. These categories overlap, because some independent works still can be linked to particular texts, etc. 
In his writings, Śākya Mchog Ldan argues against identifying the buddha-essence as a mere natural purity (rang bzhin rnam dag), i.e., the state of natural freedom from obscurations as it is taught in the Middle or Second Wheel of Doctrine (chos 'khor, dharmacakra) and its commentaries. The buddha-essence has to be posited as inseparability from positive qualities of a buddha. ${ }^{9}$

Śakya Mchog Ldan approaches the buddha-essence inseparable from positive qualities of a buddha in two ways. In some texts, such as the Essence of Sütras and Tantras, he argues that it has to be identified only as purity from adventitious stains, i.e., the removal of all or some negative qualities that prevent one from directly seeing the buddha-essence. ${ }^{10}$ In other texts, such as The Sun Unseen Before, he interprets it as the purity from adventitious stains and the natural purity as it is taught in some sūtras of the Third Wheel of Doctrine and their commentaries. ${ }^{11}$ That type of natural purity is understood as the state of natural freedom from all obscurations inseparable from positive qualities of a buddha. Thereby, in this second type of texts, Śākya Mchog Ldan arrives at positing two types of the buddha-essence: relative (kun rdzob, samvrti) and ultimate (don dam, paramārtha). Despite different interpretations of the natural purity, the identification of the buddha-essence as the purity from adventitious stains is present in both. ${ }^{12}$

9 In the Answers to the Questions of Blo Mchog (Blo mchog pa'i dri lan), vol. 17, 564-565, Śăkya Mchog Ldan writes: "That very naturally pure sphere which became inseparable from the phenomena of positive qualities of powers, etc., is called the "buddhaessence".... In brief, it is not permissible to identify the essence merely as the natural purity. It has to be posited as inseparablity from the positive qualities of powers, etc." These positive qualities are the ten powers (stobs bcu, daśabala), four fearlessnesses ( mi 'jigs pa bzhi, catvāravāiśäradya), eighteen unshared qualities of a buddha (sangs rgyas kyi chos ma'dres pa bco brgyad, aśțadaśâvenikabuddhadharma), and the thirtytwo major marks (mtshan bzang po sum cu rtsa gnyis, dvatriṃśadvaralakșaṇa). For the detailed list, see Jikido Takasaki, A Study on the Ratnagotravibhāga (Rome: Istituto Italiano per il Medio ed Estremo Oriente, 1966), 120-121. (Hereafter, A Study).

10 As will become clear from the discussion that follows, even a complete freedom from afflictions attained by Śrāvaka and pratyekabuddha arhats is not sufficient for acquiring the buddha-essence free from adventitious stains, whether partially or completely.

11 Timewise, texts written close to the end of his life (such as $24,8,14,10$ on the list), tend to reflect this second approach.

12 Notice that in general, even when Śākya Mchog Ldan does not identify the natural purity as the state endowed with positive qualities of a buddha, he admits that the buddha-essence has qualities of both the natural purity and the purity from adventitious stains. For example, in his Enjoyment Ocean of Scriptural Statements and Reasoning Differentiating One's Own and Others' Tenets: Explanation of Difficult Points of the "Ornament of Clear Realizations" Treatise of the Quintessential Instructions on the Perfection of Wisdom Together With Its Commentaries (Shes rab kyi pha rol tu phyin pa'i man ngag gi bstan bcos mngon par rtogs pa'i rgyan 'grel pa dang bcas pa'i dka' ba'i gnas rnams rnam par bshad pa rang gzhan gyi grub mtha' rnam par dbye ba lung rigs kyi rol mtsho), vol. 2, 121 (hereafter, Enjoyment Ocean of Scriptural Statements and Reasoning), addressing the question of complete realization of the essence, Saakya Mchog Ldan argues that the essence can be split into two parts (cha): that of natural purity and that of purity from adventitious stains. The first one is realized completely from the first bodhisattva-ground, while the second one is realized completely only in the buddha-ground. Nevertheless, although Śākya Mchog Ldan explaines that the buddhaessence has a part of the natural purity, he does not identify it as the natural purity itself in that context. There, he is dealing with just one type of the buddha-essence with two parts or aspects, not two types of the buddha-essence, as in The Sun Unseen Before. 
In his interpretation of the buddha-essence, Śākya Mchog Ldan utilizes the categories of the three levels found in the Sublime Continuum: the impure (ma dag, aśuddha), impure-pure (ma dag dag pa, aśuddhaśuddha, i.e. partially pure) and very pure (shin tu rnam dag, suviśuddha) levels that correspond respectively to the categories of sentient beings, bodhisattvas (understood as ārya bodhisattvas in this context), and tathāgatas. Śākya Mchog Ldan argues that one becomes a possessor of the buddha-essence free from adventitious stains only on the impure-pure level. In other words, when bodhisattvas enter the Mahāyāna Path of Seeing (mthong lam, darśanamārga) simultaneously with the attainment of the first boddhisattva ground (byang chub sems pa'i sa, bodhisattavabhūmi) of Utmost Joy (rab tu dga' ba, pramuditā), they become āryas, i.e. "exalted" or "superior", bodhisattvas, directly realize the ultimate truth (don dam bden pa, paramärthasatya), and thereby for the first time generate an antidote to obscurations of knowables (shes bya'i sgrib pa, jñeyāvaraṇa). They start gradually removing them, and thereby actually see at least a partial purification of stains "covering" the buddha-essence, and its inseparability from at least some positive qualities. Such is not possible for anyone below that level, even for the non-Mahāyāna arhats (i.e., śrāvakas and pratyekabuddhas). Thus, only Mahāyāna āryas have the buddha-essence characterized by the purity from adventitious stains; ārya bodhisattvas have only a part of it, while buddhas have it completely. ${ }^{13}$

13 I located only one text that does not comply with this approach: the Ocean of the Meaning of Scriptural Statements: Extensive Explanation of the Body and Branches of the Perfection of Wisdom Sütras and the "Ornament of Clear Realizations" Together with Commentaries (Shes rab kyi pha rol tu phyin pa'i mdo dang mngon par rtogs pa'i rgyan 'grel dang bcas pa'i lus dang yan lag rgyas par bshad pa lung don rgya mtsho), vol. 3. But it was written by Śākya Mchog Ldan very early in his life, in 1454, before the "crystallization period." While many ideas in this text are similar to what Śăkya Mchog Ldan says about the buddha-essence in his later writings, the definition of the sugata-essence Sākya Mchog Ldan gives there is different: "the sphere of natural purity [of] mind." Śăkya Mchog Ldan elaborates: "In brief, one and the same reality of mind in the mental continuum of sentient beings is called 'lineage' and 'element' from the perspective of having stains; it is called 'sugata-essence' from the perspective of being naturally pure" (76-77). Thus, the natural purity is taken as the defining characteristic of the essence, and Śākya Mchog Ldan accepts that all sentient beings possess the buddha-essence. Nevertheless, according to Sākya Mchog Ldan's biography, the Detailed Analysis of the Biography of the Great Pandit Śákya Mchog Ldan (Pandita chen po Śākya mchog ldan gyi rnam par thar pa zhib mo rnam 'byed pa), vol. 16, 70, by Kun dga' grol mchog, and according to Śăkya Mchog Ldan himself in the colophon of that early text, he followed his teacher, Rong ston shes bya kun rig (1367-1449), when he wrote it. Furthermore, in the Resolved Thorough Clarification or Thorough Clarification of the Definitive Meaning: Abundant Discourse Eliminating Qualms Issuing from the "Golden Spoon" (Gser gyi thur ma las brtsams pa'i dogs gcod kyi 'bel gtam rab gsal rnam nges sam / nges don rab gsal), vol. 17, 505 (hereafter, Resolved Thorough Clarification), Śākya Mchog Ldan admits that when commenting on the Ornament of Clear Realizations with its commentaries, scholars of the past explained that all sentient beings are possessors of the essence, and that he explained this as well. Nevertheless, continues Sākya Mchog Ldan, it was done with the essence taught in the Middle Wheel in mind. (Most probably, Śākya Mchog Ldan alluded to this earliest commentary on the Ornament of Clear Realizations, which he wrote.) 
In the Meaningful to Behold: Answers to the Questions of Spiritual Friend Mus Pa Rab 'Byams $\mathrm{Pa},{ }^{14}$ Śăkya Mchog Ldan explains that the clearest identification of the essence in the Sublime Continuum is given in the following passage from the first chapter (verses 154-155): ${ }^{15}$

There is nothing to eliminate here,

Nothing at all to establish.

Reality is to be viewed as reality.

Having seen [it], one is liberated.

The element (khams, dhätu) is empty of the adventitious [defilements]

Which have the character of being separable (rnam dbyer bcas pa, savinirbhāga) [from it].

It is not empty of unsurpassed [qualities]

Which have the character of not being separable (rnam dbyer med pa, avinirbhāga) [from it].

He argues that in the passages from Asanga's Explanation that immediately precede and follow these verses, only the suchness (de bzhin nyid, tathatā) free from adventitious stains is explained as the essence. Furthermore,

That very [essence] in general is the dharma-body (chos sku, dharmakāya) free from adventitious stains. That [its] boundary is taken [to begin] from the first [bodhisattva] ground is clear from the actual commentary [by Asanga] on this very [passage]. The way of that essence not being completely seen directly because [the viewer] is not a complete buddha is also clear from the commentary that follows this very [passage]. ${ }^{16}$

The close connection between seeing the buddha-essence free from adventitious stains and having it, as well as between becoming free from adventitious stains and acquiring positive qualities of a buddha, is a prominent feature of Śákya Mchog Ldan's interpretation of the buddha-essence. This approach is followed even in very late texts that Śäkya Mchog Ldan wrote just a few years before he passed away. ${ }^{17}$

If a partial removal of defilements and a partial acquisition of positive qualities of a buddha is sufficient for becoming a possessor of the essence

14 Bshes gnyen mus pa rab 'byams pa'i dri lan mthong ba don ldan, vol. 23. (Hereafter, Meaningful to Behold.)

15 Here and below, I provide the verse numbers of the first chapter given in A Study. My translation of the verses of the Sublime Continuum was greatly aided by an unpublished manuscript of an English translation of its first chapter by Jeffrey Hopkins, that, at times, I use almost verbatim.

16 Meaningful to Behold, 409-410.

17 One of the clearest examples of this approach can be found in the Answers to Objections to the "Establishment of the Original Buddha" Text (Dang po'i sangs rgyas grub pa'i gzhung gi brgal lan), vol. 13, 145. Śākya Mchog Ldan explains why not everyone has the essence: until one directly sees that stains are primordially non-existent, "Until then, the supreme primordial mind on the level of the basis // Cannot be known as the dharma-body. // When that [non-existence of stains, etc. is directly] seen, when that is known, from that time on, // One knows that [s/he] himself/herself has // One part of the buddha-essence." This can happen only from the first bodhisattva-ground. 
(snying po can), does it mean that a partial buddha-essence is a genuine buddha-essence?

In the majority of his writings on the buddha-essence, including the Essence of Sūtras and Tantras, Sākya Mchog Ldan answers this question positively. ${ }^{18}$ Only in a few texts addressing the issue of the buddhaessence does Śākya Mchog Ldan not elaborate on the question, ${ }^{19}$ and in one text he answers it negatively. ${ }^{20}$ These "discrepancies" occur because in some textual passages Śakya Mchog Ldan argues from the perspective of someone else's view, which is not necessarily his own. The view

18 For example, in the Essence of the Ocean of Scriptural Doctrines: Condensation of Desiderata of General Meaning of the "Ornament of Clear Realizations" with Its Commentaries (Mngon par rtogs pa'i rgyan 'grel pa dang bcas pa'i spyi'i don nyer mkho bsdus pa lung chos rgya mtsho'i snying po), vol. 3, 293-294, Śākya Mchog Ldan writes: "[Identification of the buddha-essence is as follows]: suchness inseparable from a buddha's positive qualities, [such as] powers, etc. If it is divided without distinguishing between the actual and imputed one [i.e. the actual division can be made only when both parts are actual], the genuine one is the reality pure of adventitious stains (glo bur rnam dag gi chos nyid), while the imputed one is the naturally pure reality (rang bzhin rnam dag gi chos nyid). The first one also [is of two types]: the complete one-a buddha's reality pure of adventitious stains, and the partial one-the ten [bodhisattva] grounds' reality pure of adventitious stains. Śravaka and pratyekabuddha āryas do not have it because they do not have dharma body and nirvāna. It is not the same for ārya bodhisattvas because in the [Maitreya's] Ornament of the Mahāyāna Sūtras (Mahāyānasūtrālaṃkara), [Asañga's] commentary on the Sublime Continuum, and [Nāgārjuna's] Praise to the Dharma-Sphere (Dharmadhātustotra) it is explained that the dharma-body pure of adventitious stains exists from the first ground on, and because in [Candrakirti's] Commentary on [Nāgārjuna's] "Sixty Stanzas of Reasoning" (Yuktișașțikāvrttti),it is said that nirvāna is manifested from the first ground." (Hereafter, Essence of the Ocean of Scriptural Doctrines.)

19 For example, in the section of the Golden Spoon that deals with Sa skya Pandita's interpretation of the buddha-essence in the first chapter of the Clear Differentiation of the Three Codes, Śakya Mchog Ldan does not elaborate on the difference between Mahāyāna āryas and sentient beings having versus not having the buddha-essence. As I understand him, he does it precisely because according to Śākya Mchog Ldan, Sa skya Pandita himself did not clearly explain the distinction between the dharmabody with complete and incomplete positive qualities (Enjoyment Ocean of Scriptural Statements and Reasoning, vol. 1, 505-507). To introduce it there would probably be out of context.

20 In the Resolved Thorough Clarification, vol. 17, 513, Sākya Mchog Ldan argues that although ārya bodhisattvas have parts of the essence, they do not have a genuine essence (snying po mtshan nyid pa), precisely because it is incomplete, like a mere part of someone's body cannot be counted as the body. Unless Śăkya Mchog Ldan openly contradicted himself (which is also possible, given the fact that throughout his life Śākya Mchog Ldan kept exploring and updating his views), my provisional answer is as follows: as Sākya Mchog Ldan explains in the Meaningful to Behold, the essence with incomplete inseparable qualities is not the essence explicitly taught (dngos bstan) by the sütras that the Sublime Continuum deals with. Those sutras teach the essence with all positive qualities of a buddha being complete. On the level of the path, the reality (chos nyid, dharmatā) free from adventitious stains in the mental continuum of [ārya] bodhisattvas is one part of the actual buddha-essence. But because it does not have all positive qualities, continues Śăkya Mchog Ldan, it is not the actual essence explicitly taught by the sütras of the Sublime Continuum (413-414). So, it is possible that when in the Resolved Thorough Clarification,Śakya Mchog Ldan stated that such essence is not a real essence, this statement was made from the point of view of those sūtras, not from the point of view of the Sublime Continuum as Śākya Mchog Ldan understands it, and by extension, not from Śākya Mchog Ldan's own point of view. (As will become clear from the discussion below, Sākya Mchog Ldan accepts the view of the Sublime Continuum as definitive, and agrees with its explanation of those sutras as interpretive and non-literal.) 
he explicitly declares as his own can be found in the Enjoyment Ocean of Scriptural Statements and Reasoning. That text has an extensive chapter on the buddha-essence containing a section called "Presentation of the system conceived by my own mind" (rang gi blos rnam par btags pa' $i$ lugs rnam par bzhag pa). ${ }^{21}$ In that section, Śākya Mchog Ldan argues that the buddha-essence exists from the first bodhisattva ground, ${ }^{22}$ and also explains:

The illustration of the actual [buddha-]essence is a dharma-body which is pure of adventitious stains and is inseparable from the positive qualities of powers, etc. It is also of two types: the essence on the very pure level, called "emptiness endowed with the supreme of all aspects" (rnam kun mchog ldan gyi stong nyid, sarvākāravarop etāśūnyatā), with all parts [of positive qualities] complete; and the one with the parts of the dharma-body not being fully complete: the one called the "dharma-body free from adventitious stains" (blo bur rnam dag gi chos sku) on the pure-impure level. ${ }^{23}$

Not only that: Śakya Mchog Ldan explains that the synonyms of the sugataessence are tathāgata, the ultimate of the āryas' truths ('phags pa'i bden $p a^{\prime} i$ don dam), and nirvāna, ${ }^{24}$ and goes as far as making the following statement:

Question: Is it possible to accept the existence of a sugata, buddha, dharma-body, and nirvāna on the [level of] the path of learners (slob lam)?

Answer: Such is accepted. Because of that [very] reason, the words "truly perfect" (yang dag par rdzogs pa, samyaksam-) have to be added [to the word "buddha" on the resultant level] $\ldots{ }^{25}$

In other words, Śākya Mchog Ldan accepts the existence not only of the buddha-essence, but the dharma-body, etc., on the level of the Mahāyāna āryas.

These and other passages we will be dealing with below, as well as multiple statements in other texts addressing the buddha-essence directly and indirectly, convince me that Śakya Mchog Ldan's own view is that the buddha-essence pure from adventitious stains exists only from the first bodhisattva-ground onwards, and that even a partial buddha-essence is the buddha-essence.

In relation to this issue, I should address yet another question: what is the meaning of the inseparability of the essence from positive qualities of a buddha?

21 This section starts in vol. 1, 487.

22 Ibid, 503.

23 Ibid, 500.

24 Ibid, 497.

25 Ibid, 502. 
In the Essence of the Ocean of Scriptural Doctrines, ${ }^{26}$ Sākya Mchog Ldan explains that there are two types of inseparability: when it is said in the Sublime Continuum that there is no nirvāna apart from buddhahood, what is intended is the inseparability from all positive qualities of a buddha, while the inseparability on the ten grounds is the inseparability from individual (re re ba)-or "some"-qualities of the buddha. Furthermore, in the Cleansing the Heart Darkness with the Appearance of the Sun of Definitive Meaning: Description of Realizations of the Glorious Being of Great Nature Honorable Ārya Nāgārjuna ${ }^{27}$-in the context where the natural purity endowed with all positive qualities of a buddha is not addressed-Śākya Mchog Ldan explains that the inseparability of the ten powers of a buddha, etc., means that those positive qualities become mixed ('dres par 'gyur) with the nature of the primordial mind, the dharma-sphere (chos dbyings, dhramadhātu). Although powers, etc., do not primordially exist, these powers, etc., become the dharma-sphere when stains are purified, in the same way that rivers become inseparable from the ocean when they have flown into it.

In the Meaningful to Behold too, Saakya Mchog Ldan further explains that the inseparability has to be posited as the purity from adventitious stains, not the natural purity, and that the inseparability from individual positive qualities exists even from the first bodhisattva-ground, but not before that. In his reply to the objection that if such is the case, then it will follow that previously non-existent qualities are newly acquired, Sākya Mchog Ldan writes:

It is not [the case that] previously non-existent positive qualities are newly placed [on the essence] like an ornament put on the body. Rather, it is said so with respect to the naturally luminous mind itself being born as the entity of positive qualities free from adventitious stains. [On the other hand,] no matter how long that [primordial mind] is accompanied by stains, it is impossible [for it] to assume the entity of stains (dri ma'i ngo bor song). Therefore, the convention of "previously having stains" is not applied. ${ }^{28}$

In other words, when no natural purity endowed with positive qualities of a buddha is accepted, and no division into the relative and ultimate buddha-essence is made, Śakya Mchog Ldan agrees that starting from the first ground, the primordial mind (ye shes, jñāna)of ārya bodhisattvas newly acquires the nature of some positive qualities of a buddha. At the same time, the primordial mind does not just have them as something distinct from itself, like stains. The suchness in the continuum of sentient beings, on the other hand, is merely suitable to become inseparable from the positive qualities, but that suchness is not actually inseparable from them. ${ }^{29}$ Likewise, it is suitable to become separated from adventitious stains, but it is not yet free from even some of them.

26 Essence of the Ocean of Scriptural Doctrines, 294.

27 Dpal bdag nyid chen po 'phags pa klu sgrub zhabs kyi rtogs pa brjod pa nges don nyin mor byed pa'i snang bas snying gi mun pa sangs byed, vol. 16, 560-564.

28 Meaningful to Behold, 411.

29 Meaningful to Behold, 414. 
Even when-as he does in The Sun Unseen Before-Śākya Mchog Ldan accepts the identification of the ultimate buddha-essence as the natural purity inseparable from all positive qualities of a buddha, he still maintains that the relative buddha-essence characterized by the purity from adventitious stains exists only from the first bodhisattva-ground.

Let us turn now to the Essence of Sütras and Tantras and The Sun Unseen Before to demonstrate the persistence of these elements of Śākya Mchog Ldan's interpretation of the buddha-essence in the two texts.

\section{The Buddha-essence in the Essence of Sütras and Tantras}

In his earlier work, Śākya Mchog Ldan explains that the Perfection Vehicle teaches two types of essence, as described in the Second (Middle) and Third (Last, Final) Wheels of Doctrine (chos 'khor, dharmacakra). The first type is the non-affirming negation (med dgag, prasajyapratiședha) of all extremes of elaborations (spros pa'i mtha', prapañcānta). It pervades all beings: ordinary sentient beings, ārya bodhisattvas, and buddhas, but does not pervade all phenomena. This type of essence is not a real buddha-essence, only an imputed one. Therefore, the Second Wheel, as well as those commentaries that agree with it (such as Candrakirti's non-tantric Madhyamaka writings), do not teach a real buddha-essence [4-5, 8, 82].

The presentation of the Third Wheel's teachings on the buddha-essence is divided by Śākya Mchog Ldan into those of sūtras and those of their treatises. Sütras are of two types: some explain that the buddha-essence endowed with all positive qualities of a buddha is present in all sentient beings. Other sūtras take this explanation as having a veiled intent (dgongs pa can), as non-literal. They interpret it by demonstrating three elements of interpretive teachings: the basis of intent (dgongs gzhi), the purpose (dgos $p a)$, and the valid cognition damaging the explicit [teaching,] (dngos la gnod byed kyi tshad ma)-or just damage to the explicit [teaching,] (dngos la gnod byed) [11-13].

Following the latter type of sūtras, Sākya Mchog Ldan argues that the basis of intent of the Third Wheel of Doctrine's teachings on the buddhaessence is the natural luminosity (rang bzhin 'od gsal, prakrtiprabhāsvara) free from all extremes of elaborations, the object of experience of the individually self-cognizing primordial mind (so so rang gis rig pa'i ye shes), which is an affirming negation (ma yin dgag, paryudāsapratiședha) [14-16]. The Sublime Continuum interprets the first type of sütras in the same way: by demonstrating the three elements of interpretive teachings, it explains that the teaching of the buddha-essence pervading all sentient beings has a veiled intent [35-50]. ${ }^{30}$ The Essence of Sütras and Tantras makes clear that the buddha-essence teachings of the Third Wheel, as well as their commen-

30 According to Śākya Mchog Ldan, the essence explicitly taught in such sūtras is taken by the Sublime Continuum as interpretative. He argues that the Sublime Continuum's explanation of the basis of intent in teaching the buddha-essence by such sutras is misinterpreted by Tibetan thinkers as the actual buddha-essence (see the Golden Spoon, vol. 6, 510). 
taries, such as Nāgārjuna's Praise to the Dharma-Sphere ${ }^{31}$ [52-54], which Śakya Mchog Ldan himself approves of, agree with the Sublime Continuum. It is not surprising then that the Sublime Continuum itself is seen as having the definitive meaning [51], ${ }^{32}$ and together with Asanga's Explanation is addressed by Śākya Mchog Ldan in so much detail.

The Sublime Continuum explains the buddha-essence in two ways (that are not presented as contradictory): explanations by the ten types of presentations (rnam gzhag rnam pa bcu) ${ }^{33}$ and by the nine examples [and their] meanings (dpe don dgu). ${ }^{34}$ In the first context, the unification (zung 'brel) of the natural purity and the natural luminosity (rang bzhin 'od gsal) is divided into three levels: impure, impure-pure, and very pure. On these levels, there exist, respectively the essence of ordinary beings, ārya bodhisattvas, and buddhas (i.e., that very unification is given those names). ${ }^{35}$ The sugataessence does not pervade all sentient beings. On the other hand, according to both the Sublime Continuum and the Explanation, only buddhas have the essence inseparable from all positive qualities. Furthermore, the four types of individuals mentioned in the Sublime Continuum (those of great desires, heretics, śrāvakas and pratyekabuddhas) cannot serve as the basis for the sugata-essence (i.e. do not have it), let alone realize it [18-25].

Thereby, this section in the Essence of Sütras and Tantras demonstrates the distinctive feature of Sākya Mchog Ldan's understanding of the buddha-essence mentioned above: nobody except the Mahāyāna āryas has the buddha-essence. The section on the nine examples demonstrates it even more clearly, culminating in verses 34-35, which state that all Mahāyāna āryas have the sugata-essence, while other sentient beings are only imputed as possessors of such essence. How does Śākya Mchog Ldan arrive at this conclusion?

In the discussion of the nine examples [25-36], the statement that the essence pervades all sentient beings is explained as intentional. What is

31 Dharmadhātustotra, Chos kyi dbyings su bstod pa, D1118, ka, 63b-67b.

32 When dealing with this text written in verse, numbers in square brackets indicate the verse numbers that are provided in my translation.

33 The ten types of presentations are listed in verse 29 of the first chapter of the Sublime Continuum. They are the presentations of (1) entity (svabhāva, ngo bo), (2) causes (hetu, rgyu), (3) result (phala, 'bras bu), (4) function (karman, las), (5) possession (yoga, ldan pa), (6) occurrence (vrtti, 'jug pa), (7) levels (avasthāprabheda, gnas skabs), (8) omnipresence (sarvatraga, kun tu 'gro ba), (9) unchangeability (avikāra, $m i$ 'gyur ba), and (10) inseparability (abheda, dbyer med) of positive qualities. Their discussion begins in verse 30 of the Sublime Continuum and ends in verse 95. They are discussed by the following verses: presentations $1-2$ : verses $30-34 ; 3-4$ : verses 35-41; 5: verses 42-44; 6: 45-46; 7: 47-48; 8: 49-50; 9: 51-83; 10: 84-94. In the Enjoyment Ocean of Scriptural Statements and Reasoning, vol. 1, 503, Śākya Mchog Ldan explains that the meaning of the ten presentations is complete starting from the first ground.

34 Their discussion starts in the verse 95 of the first chapter of the Sublime Continuum. Verses 96-97 provide the list of the nine examples: (1) a buddha inside an ugly lotus, (2) honey amidst bees, (3) a kernel inside a husk, (4) gold within filth, (5) a treasury in the earth, (6) stalks, etc., inside a small seed, (7) a buddha's image inside a tattered garment, (8) a universal monarch in the womb of an ugly woman, (9) a precious golden image in an earthen mold.

35 Notice that in the context of this threefold division in the Sublime Continuum, ārya bodhisattvas are not called "sentient beings." Thus, sentient beings are everyone but Mahāyāna āryas. 
intended is threefold: dharma-body (dharmakāya, chos sku), suchness (tathatā, de bzhin nyid), and lineage (rigs, gotra). These three do not simply overlap with the buddha-essence and each other. Rather, they are different aspects of enlightened and unenlightened states, not all of which are the buddha-essence:

- The dharma-body is of two types: "the dharma-sphere free from adventitious stains, and its concordant causes." The dharma-body is the buddha-essence.

- The suchness is understood only as the natural purity. The suchness pertains to all phenomena, not just sentient beings, etc. It is of two types: one is, and the other is not the buddha-essence. ${ }^{36}$ The suchness is also subdivided into that of buddhas, ārya bodhisattvas, and the four types of individuals mentioned above (by extension, all the rest of beings should be added to this category). The first is a complete dharma-body, and the second is its part. The third is not even a part of the dharmabody and therefore is not the buddha-essence. ${ }^{37}$

- The lineage, including the naturally abiding lineage (rang bzhin gnas rigs) and the developing lineage (rgyas 'gyur gyi rigs), together with the subdivisions of the latter, is not the buddha-essence. It is an exclusive property of sentient beings.

When we put together the categories discussed so far in the two explanations, they will be distributed throughout the three levels in the following way:

- very pure level: buddha-essence, essence inseparable from all positive qualities, fully complete dharma-body, suchness of buddhas;

- impure-pure level: buddha-essence, essence of ārya bodhisattvas, suchness of ārya bodhisattvas, parts of the dharma-body;

- impure level: essence of ordinary beings, suchness of ordinary beings, dharma-sphere of the four individuals (and sentient beings in general), lineage.

As we can see, the buddha-essence is found only on the impure-pure and very pure levels. Śăkya Mchog Ldan further reiterates that interpretation when he turns to the discussion of the three elements of interpretive teachings. He explains that only when the antidotes of obscurations of the buddha-essence are produced is the person who produced them described as a possessor of the buddha-essence [40-41]. Summarizing his position, and making a distinction between a mere buddha-essence (snying po tsam) and the essence ornamented with the major and minor marks (mtshan dpe yis spras pa'i snying po) of a buddha, Śākya

36 As mentioned above, Śākya Mchog Ldan argues against identifying a mere natural purity as the buddha-essence. Nevertheless, as it is clear from this discussion, the natural purity in combination with the purity from adventitious stains is identified as the essence. (See note 12.)

37 In other words, the suchness of buddhas is a fully complete dharma-body, while that of ārya bodhisattvas is only a part of the dharma-body. The suchness of ordinary beings is not dharma-body at all. As we have seen above, the dharma-body of buddhas and ārya bodhisattva is the buddha-essence. 
Mchog Ldan once again reiterates that sentient beings have neither of them [49]. As this discussion demonstrates, only Mahāyāna āryas have the buddha-essence.

Moving to Asanga's Explanation, Śākya Mchog Ldan argues that it also teaches that the buddha-essence exists from "the ground of the Utmost Joy through to the buddha-ground," and that only Mahāyāna āryas have the buddha-essence [55-56]. Even when it is said in the Sublime Continuum that ārya bodhisattvas see the essence in places of animal rebirth, it does not mean that all beings have the buddha-essence. Rather, when ārya bodhisattvas see a partial purity from adventitious stains covering their own reality (chos nyid, dharmatā) of their being, they see all sentient beings also in a similar way [64-67].

Discussing Asañga's commentary, Śākya Mchog Ldan argues once again that the essence cannot be identified as the natural purity; it has to be understood as the purity from adventitious stains [56-61] (though not necessarily a complete one). The suchness with stains (dri ma dang bcas $p a^{\prime} i$ de bzhin nyid, i.e., the natural purity of those who are not fully enlightened, and therefore have stains) is not the essence also because it is the dharma-body free from adventitious stains that has to be the essence [62-64]. Although the nature with stains is taught as the basis of intent of the sugata-essence, ${ }^{38}$ it is not explained as the sugata-essence itself. To be posited as the actual sugata-essence, at least one part of stains has to be purified [71-74]. This approach corresponds exactly with Maitreya's view in verses [40-41].

Śakya Mchog Ldan concludes his discussion of Asanga's view with the statement that there are two types of the buddha-essence: compounded ('dus byas, samskrtta) and uncompounded ('dus ma byas, asampskrta), ${ }^{39}$ rela-

38 In other words, the Buddha's intent behind the non-literal teachings of the buddhaessence pervading all beings is based on the nature with stains.

39 As we have already seen above, Śākya Mchog Ldan views the buddha-essence as the primordial mind.Furthermore, it is a characteristic featureof Śākya Mchog Ldan'sviews in general to interpret the primordial mind as impermanent, and in particular, as we are going to see in The Sun Unseen Before, 116, even the ultimate buddha-essence is impermanent ( $\mathrm{mi}$ rtag pa, anitya). Therefore, a simple equation of compounded $=$ impermanent and uncompounded = permanent is not applicable in this context. Let me clarify this issue with the help of the Golden Spoon and the Seventeen Wondrous Answers. In the Golden Spoon, Saakya Mchog Ldan discusses the boundaries of positing ('jog mtshams) compounded and uncompounded phenomena in the context of the four last Doctrines of Maitreya, where the entity of the dharma-sphere (chos dbyings, dharmadhätu) is identified as the primordial mind free from duality of apprehendedapprehender (gzung 'dzin gnyis med kyi ye shes). Śākya Mchog Ldan explains that "it has to be accepted as impermanent: because it is a functional thing (dngos po), it has to be accepted as momentarily disintegrating (skad cig gis 'jig pa). Nevertheless, it does not contradict its being explained as permanent in other contexts: it is explained in that way with the permanence of continuity (rgyun gyi rtag pa) in mind" (498). Dealing with the question whether the dharma-sphere is compounded or not, Śākya Mchog Ldan says that in general, Buddhist teachings explain three types of "compounded": (1) that which undergoes production, disintegration, and abiding (skye 'jig gnas gsum); (2) that which is compounded ('dus byas pa) in the sense of being produced by karmas and afflictions, or by the ground of habitual tendencies of ignorance (ma rig bag chags kyi sa), etc.; (3) that whose own entity (rang gi ngo bo) is newly fabricated by causes and conditions (rgyu rkyen gyis gsar du bcos pa). In another text, the Seventeen Wondrous Answers (vol. 23, 462-466), Śākya Mchog Ldan explains that the Doctrines of Maitreya teach two types of primordial mind: the 
tive and ultimate [76-79]. I see the interpretive approach followed by Śākya Mchog Ldan in The Sun Unseen Before as an attempt to unpack and clarify the issue of the two types of the buddha-essence mentioned only briefly in the Essence of Sūtras and Tantras. As we are going to see, Śākya Mchog Ldan's "updated" interpretation of the natural purity affected his view of the buddha-essence. But despite this, Sākya Mchog Ldan retained the two characteristic features of his view of the buddha-essence addressed above. To demonstrate that, let me turn now to The Sun Unseen Before.

\section{The Buddha-essence in The Sun Unseen Before}

At the beginning of his Sun Unseen Before, Sākya Mchog Ldan makes a statement that at first glance may seem to contradict what he explained in his earlier Essence of Sütras and Tantras. He argues that the main topic of the Sublime Continuum is "the primordial mind of the dharma-sphere that, from the beginning, intrinsically has all the positive qualities of powers, and so on," and abides in "all buddhas and sentient beings."[115]. ${ }^{40}$ At the end of the text, Sākya Mchog Ldan reiterates this idea once more:

naturally pure primordial mind (rang bzhin rnam dag gi ye shes) and the primordial mind pure from adventitious stains (glo bur rnam dag gi ye shes). They are discussed on three different levels of the basis, path, and result. On the level of the result, they are distinguished only by way of isolates (ldog pa, vyatireka). On the level of the path, the purity from adventitious stains is only temporary, and on the level of the basis, only natural purity exists. Thus, the naturally pure primordial mind is uncompounded on all three levels because it (i.e., its continuity) is not something non-existent previously that is newly produced, and at the end, it cannot undergo destruction of the continuity of a similar type (rigs 'dra rgyun bcad kyi 'jig pa). Nevertheless, it is a functional thing (dngos po) and a cause (rgyu, hetu). The primordial mind pure of adventitious stains is identified as the path of release (rnam par grol ba'i lam, vimuktimärga) on the level of the path, and therefore it has not only the immediately preceding condition (de ma thag pa'i rkyen, samanantarapratyaya)-as the naturally pure primordial mind does-but it is also produced from other causes, such as the unobstructed path (bar chad med lam, ānantaryamārga), etc. Therefore, argues Śākya Mchog Ldan, since it is impermanent in that sense, it is relative. Clarifying his position, he explains that what is called "the primordial mind pure of adventitious stains" is a combination of the primordial mind and the negation of adventitious stains. When they are not separated, such primordial mind pure of adventitious stains is posited as relative. But when they are separated, the primordial mind part (ye shes kyi cha) is taken to really exist, but the part of separation (bral cha) or negation is not.

This line of reasoning helps to understand the statement that the buddha-essence can be treated as compounded and uncompounded: being the primordial mind, the buddha-essence too is impermanent in the sense of undergoing momentary change, and therefore is the first of the three types of compounded phenomena described in the Golden Spoon. It is never the second type. Can the buddha-essence be the third type of compounded phenomena mentioned in the Golden Spoon? When the buddha-essence is identified as the purity from adventitious stains, then similarly to the primordial mind pure of adventitious stains, on the level of the path it is the third type of compounded phenomena. Interestingly, it follows that only the relative essence (the primordial mind free from adventitious stains) is the actual essence on the level of the path, and what is the ultimate and uncompounded-i.e., the naturally pure primordial mind pervading all beings-is not a real essence but only the basis of intent (dgongs gzhi)of it, according to the Essence of Sütras and Tantras. On the other hand, the essence naturally pure of adventitious stains as it is explained in The Sun Unseen Before is neither the second nor the third type of compounded phenomena described in the Golden Spoon.

40 Hereafter, the numbers in square brackets correspond to the page numbers of the Tibetan text of The Sun Unseen Before. 
Therefore, the suchness that is naturally pure from all faults, and [has] multiplicity of positive qualities of powers, etc., present in a natural, spontaneous way, is the actual essence identified as the very topic of this text [of the Sublime Continuum] [122].

Nevertheless, immediately after that statement at the beginning of the text, Śākya Mchog Ldan specifies that there are indeed two types of the essence: the relative essence ( $k u n$ rdzob pa'i snying po) and the ultimate essence (don dam pa'i snying po), in the same way as there are two types of buddhas and two types of sentient beings. The relative essence is newly acquired, while the ultimate one exists forever.

Against this modified and expanded background, Śākya Mchog Ldan approaches the question of possession of the buddha-essence quite differently. He splits both the essence and beings into two types, the ultimate and the relative, and concentrates on the issue of the ultimate essence pervading ultimate beings, and the relative essence pervading relative beings. Never in this text does he address the issue of "cross-pervasion," so to say: the ultimate essence pervading relative beings, and vice versa. But Sākya Mchog Ldan does mention once that the teaching of the essence with complete characteristics of purity from adventitious stains pervading sentient beings is interpretive [118]. In other words, as in the Essence of Sütras and Tantras, he argues that not all beings have the buddha-essence. Let us look now at the line of arguments Śākya Mchog Ldan follows in The Sun Unseen Before.

According to The Sun Unseen Before, the relative essence and the relative buddha have the same meaning, and they are identified as the state of freedom from all faults and the perfection of all positive qualities that appears to those beings who are not fully enlightened [115]. The ultimate essence, the ultimate buddha, and ultimate sentient beings in their turn also have the same meaning, which is the state of natural purity from all objects of abandonment and natural accomplishment of all positive qualities. In other words, it is the ultimate reality that is inseparable from all positive qualities of a buddha and free from all obscurations. Precisely because it is "naturally pure of all its objects of abandonment, it [also] has to have all positive qualities naturally accomplished" [115]. Therefore, it can be said that the reply to the question whether ultimate sentient beings have the ultimate buddha-essence is: the ultimate sentient beings are the ultimate buddha-essence.

Relative sentient beings are understood as beings of six types (humans, animals, etc.) [115]. Do all of them have the relative buddha-essence or not? Answering this question, Śākya Mchog Ldan takes us back to the now familiar world of the Essence of Sütras and Tantras. He argues against all relative sentient beings possessing the relative essence, because even on the relative level, the essence is not identified as having obscurations, while sentient beings do have obscurations [115]. In other words, to become a possessor of the buddha-essence, one has to acquire at least some positive qualities of a buddha. We know already that according to the Sublime Continuum, such happens only from the first bodhisattva-ground. 
As the following passages demonstrate, despite the dramatically expanded context in which The Sun Unseen Before operates, the status of the relative essence is neither lowered nor heightened:

In the unique [teachings] of the Pronouncement of the Third Wheel also, it is explained that the relative essence fulfills the role of the essence conventionally. Nevertheless, it is not asserted even conventionally that it pervades all sentient beings. This is because in that context, the presentation of the five paths and the ten grounds has to be asserted as gradual. [117].

Also:

As for the relative essence, because there are explained dissimilar divisions of newly seeing the dharma-body, starting from the first [bodhisattva] ground until the buddha-ground, it is possible to explain the existence of dissimilar divisions [of the essence] by way of [its] positive qualities [120].

A lengthy discussion of the False Aspectarian Madhyamaka's 41 interpretation of the relationship between the primordial mind and consciousness [120-122] is intended to further clarify the nature of the two buddha-essences because, as the text demonstrates, the relative essence appears only to consciousness, while the ultimate essence is realized only by the primordial mind. If there are any doubts left about relative beings having the ultimate buddha-essence, they are cleared away by the examples of the sky (exemplifying the primordial mind) and clouds (exemplifying consciousness), etc. They show that relative sentient beings possessing the ultimate essence makes no more sense than the clouds possessing the sky.

As The Sun Unseen Before demonstrates, while Śăkya Mchog Ldan developed and clarified the category of the ultimate essence, he kept the issue of all sentient beings possessing the buddha-essence on the same level as in the Essence of Sütras and Tantras.

It is difficult to overestimate the ingenuity of Sākya Mchog Ldan's approach in The Sun Unseen Before. As he explains at the end of the text, the Buddha himself taught on some occasions that sentient beings have the buddha-essence, and on other occasions that they do not, and in order to explain his intent behind these teachings, Maitreya presented two types of the buddha-essence based on the two truths. Therefore, although Śākya Mchog Ldan says that no other Tibetans ever explained the buddha-essence in such a way, he does imply that his own unique explanation

41 Śākya Mchog Ldan accepts the division of Yogācāra system into False Aspectarians (i.e., those Yogācārins who accept minds appearing as external objects to be false) and True Aspectarians (i.e., those Yogācārins who accept minds appearing as external objects to be true). At the same time, he treats the False Aspectarian Yogăcāra as Madhyamaka, in contrast to the True Aspectarian Madhyamaka that he treats as Cittamătra, not Madhyamaka. According to Śākya Mchog Ldan, the Sublime Continuum is the False Aspectarian Madhyamaka / False Aspectarian Yogācāra treatise. 
is grounded in the Sublime Continuum, and ultimately in the teachings of the Buddha himself.

Armed with this double-edged sword with the ultimate and conventional blades, Sākya Mchog Ldan can cut through the thicket of diverse teachings on the buddha-essence, including his own. In The Sun Unseen Before, Śakya Mchog Ldan makes it clear that when it is taught that everyone has the buddha-essence, what is intended is arguably the ultimate buddha-essence. When it is stated that the buddha-essence does not pervade all sentient beings, it is arguably the relative essence. Likewise, when some texts or passages within a particular text, such as the Sublime Continuum, explain the teachings of the essence pervading all sentient beings as intentional, the essence addressed in such a context is the relative essence pervading all relative beings, with newly abandoned stains and newly acquired positive qualities. When such teachings are explained as definitive, the essence addressed in that context is the ultimate essence pervading all ultimate sentient beings.

\section{Conclusion}

Śakya Mchog Ldan's writings demonstrate that the idea of only the Mahāyāna āryas possessing the buddha-essence is the most complicated element of his interpretation of the buddha-essence. This idea is closely linked with the idea of the inseparability from the positive qualities of a buddha. Clearly, these two elements of Śakya Mchog Ldan's interpretive approach to the buddha-essence can be fully appreciated only in their relationship. These elements persisted through both texts discussed here, despite the dramatically changed setting that is based on different notions of the natural purity. Because of that difference, the Essence of Sütras and Tantras describes the buddha-essence as the purity from adventitious stains, while The Sun Unseen Before, having expanded the setting to the two purities, provides two descriptions of the buddha-essence.

Despite the notion of the two buddha-essences, Śakya Mchog Ldan is careful about keeping the two on their respective levels. This approach helps him to retain the idea that not everyone has the buddha-essence, and that the essence has to be inseparable from the positive qualities, despite the fact that according to the second text, the primordial positive qualities are forever present in the primordial mind.

Therefore, Śākya Mchog Ldan's Sun Unseen Before can be viewed as a later elaboration of the same fundamental approach to the buddha-essence that he took in his earlier years, in other words, as a new illumination of the Essence of Sütras and Tantras. By reburying the treasure of the buddha-essence deep within the ultimate minds of sentient beings, he was able to maintain the continuity of his view of the buddha-essence pure of adventitious stains existing only in the Mahāyāna āryas. 


\title{
Appendices
}

\section{The Essence of Sūtras and Tantras: Explanation of the Buddha-essence}

\author{
Namah Śrī sugatasya garbheyā. ${ }^{42}$
}

[1] I prostrate to the supreme essence of the buddha, who \{has three features: $\}^{43}$

Being free from obstructing obscurations (thogs pa'i sgrib $p a$, pratighātāvaraṇa) \{the feature of abandonment\},

And having realized thatness (de nyid, tattva) \{the feature of realization\},

Possesses the treasure of positive qualities the feature of positive qualities .

[2] Many earlier wrong ideas about this [buddha-essence] \{[such as] "there abide in all sentient beings positive qualities of the body [of the buddha] ornamented with the major and minor marks ( $m t$ shan dpe, lakșaṇavyañjana), of indestructible speech [of the buddha], and of the mind [of the buddha, such as the powers, etc."]\}

Were eliminated by scholars of the past. \{Two [of them], Sa [Skya Pandita, 1182-1251] and Rngog [Blo Ldan Shes Rab, 10591109], as well as Bu [Ston Rin Chen Grub, 1290-1364], and others stated that in the Perfection [Vehicle], the mere natural purity (rang bzhin rnam dag tsam) and the element of sentient beings (sems can gyi khams) are the essence, and in the Mantra [Vehicle], there is no occasion for all of the inanimate and animate world to be pervaded by the essence .

Now, I will eliminate \{with the [help of] scriptural statements of the root text and the commentary on the Sublime Continuum, the Two Chapters [of Hevajra, ${ }^{44}$ etc.]\}.

Contemporary wrong interpretations of the texts [that teach] it.

[3] There are two types of essence

That are clearly taught in the unsurpassible texts

Of the Perfection Vehicle (phar phyin gyi theg pa, pāramitāyāna)

And the Secret Mantra Vehicle (gsang sngags kyi theg pa, guhyamantrayāna) \{[i.e.,] the two Last Wheels and Mantra\}. 1.

[4] Two types of essence are taught In the great texts of the Perfection [Vehicle]: 1.1.

42 This line written by Śăkya Mchog Ldan in Sanskrit translates as "homage to the glorious sugata-essence."

43 This and the next few verses at the beginning of the text have some notes attached to them, written in a smaller script. I include these comments in \{\} , although I doubt that they were penned by Śākya Mchog Ldan himself.

44 Hevajratantrarājanāma, Kye'i rdo rje zhes bya ba rgyud kyi rgyal po, D417, rgyud, nga, 1b-30a. 
In the Middle Wheel, in the Purity from Karmic Obscurations Sūtra 45 and the Sūtra on the Mode of Enlightenment, $\left.{ }^{46}\right\}$ the nonaffirming negation,

In which all extremes of elaborations (spros pa'i mtha', prapañcānta) are negated,

[5] Is taught to be the essence of tathāgatas,

Sentient beings, and bodhisattvas.

It does not pervade all knowables (shes bya, jñeya).

Nevertheless, all migrators ('gro kun, sarvajagat) are possessors of that essence, [ [according to foremost venerable [Maitreya], when [he was] explaining the intent of the Middle Wheel in the Ornament of [Mahāyāna] Sūtras $\left.{ }^{47}\right\}$

[6] Because when the reality of sentient beings

Has been purified of stains,

They become tathāgatas themselves.

That [non-affirming negation] is not the actual essence.

[7] If it were, it would follow that

All uncompounded phenomena and material things (bem po, ${ }^{48}$ kanthā) /125/

Are also possessors of the buddha-essence.

In that case, those [things] too

[8] Would finally become tathāgatas.

Therefore, it is [merely] imputed as that [buddha-essence].

Thus, the Middle Wheel does not clearly teach

Even a single sugata-essence \{by teachings corresponding to the meaning of possession (ldan pa'i don)\}.

[9] That is concordant with the [essence]

Explained in the Last Wheel.

Otherwise, [from the perspective of the Middle Wheel,]

The ultimate truth would have elaborations (spros pa, prapañca),

[10] Because all dharma-spheres (chos sbyings, dharmadhätu) of the

Third Wheel of Dharma

Are affirming negations.

1.2 .

There are two ways of explaining [the essence] in the Last Wheel of Dharma:

45 'Phags pa las kyi sgrib pa rnam par dag pa zhes bya ba theg pa chen po'i mdo, Ārya karmāvaranaviśuddhināmamahāyānasūtra, D218, mdo sde, tsha, 284a-297b. (I take rnam dag in the text as short for the title of this sütra.)

46 Byang chub ji lta'i mdo.

47 Mahāyānasūtrālaṃkāra, Theg pa chen po mdo sde'i rgyan, D4020, sems tsam, phi, $1 \mathrm{a}-39 \mathrm{a}$.

48 Text: bems po. 
That of sūtras and that of treatises.

1.2.1.

[11] The first one is also of two types.

1.2.1.1.

In some sūtras $\{$ [such as] the Sūtra of the Ornament of Appearances

the Primordial Mind $\left.{ }^{49}\right\}$, it is taught that all sentient beings

Have abiding within them

The Three Bodies of a perfect buddha,

[12] Permanent (rtag pa, nitya), stable (brtan pa, dhruva), everlasting

(ther zug, śáśvata/dhruva),

Not produced by any causes,

And adorned with all the sixty-four positive qualities. ${ }^{50}$

1.2.1.2.

In some [other] sūtras [of the Last Wheel of Dharma], \{[such as] the

Descent into Lanka $\left[\right.$ [Sūtra] ${ }^{51}$ and the fourth chapter of the Great Nirvāna [Sūtra] $\left.{ }^{52}\right\}$,

[13] The above [teachings] are interpreted as having [a veiled] intent

By [demonstrating] the basis of intent and the purpose

With the examples of a doctor and a potter,

And by the valid cognition damaging the explicit [teaching,]

[14] [Realizing that such essence is] "equal to the self of heretics."

Therefore, the Last Wheel clearly explained

The basis of intent in [teaching] the sugata-essence

As the "natural luminosity"

[15] Free from all extremes of elaborations,

That is the object of experience

Of the individually self-cognizing primordial mind.

Thus, [this basis of intent]

[16] Has to be explained as an affirming negation.

Nevertheless, it will not turn out that in this system,

[The individually self-cognizing primordial mind] is not free from elaborations, \{because the boundaries of positing freedom from elaborations are different $\}$

Because the luminosity ('od gsal, prabhā) itself

49 Āryasarvabuddhaviśayāvatārajñānālokālaṃkāranāmamahāyānasātra, 'Phags pa sangs rgyas thams cad kyi yul la 'jug pa'i ye shes snang ba'i rgyan ces bya ba theg pa chen po'i mdo, D100, mdo sde, ga, 276a-305a.

50 See note 9.

51 Āryalañkāvatāramahāyānasūtra, 'Phags pa lang kar gshegs pa'i theg pa chen po'i mdo, D107, mdo sde, ca, 56a-191b.

52 Āryamahāparinirvāṇanāmamahāyānasūtra, 'Phags pa yongs su mya ngan las 'das pa chen po'i mdo, D119, mdo sde, nya, 1b-ta 339a; D120, mdo sde, tha 1b-151a; D121, mdo sde, tha, 151a-152b. 
[17] Is clearly called "free from extremes"

In the great treatises of Madhyamaka, Cittamātra, and Secret Mantra \{[such as Asangga's] Summary of Mahāyāna ${ }^{53}$ and Summary [of Higher Knowledge], ${ }^{54}$ the Secret Assembly [Tantra], ${ }^{55}$ the Wheel of Time [Tantra], ${ }^{56}$ and the Two Chapters [of Hevajra]\}.

1.2.2.

The way of interpreting [the buddha-essence] in the treatises [is also of two types:] Interpretation by the foremost venerable [Maitreya] himself

[18] And by the ārya masters. /126/

\subsubsection{1.}

[Maitreya's] Sublime Continuum

Has two ways of explaining [the buddha-essence]:

The explanations by the ten types of presentations

[19] And by the nine examples [and their] meanings.

1.2.2.1.1.

Due to the division of the unification (zung 'brel, yuganaddha)

Of the natural purity and the natural luminosity

Into pure, pure-impure,

[20] And very pure,

[In the discussion of "levels," the seventh presentation,]

There does exist the division [of the essence] into three:

The essence of sentient beings, bodhisattvas, and tathāgatas [respectively].

[21] Nevertheless, [in that context] it is not explained

That all sentient beings are pervaded by the sugata-essence.

[Furthermore, in his commentary on the Sublime Continuum,] ārya Asanga asserts

That the "inseparability of the positive qualities"[-the tenth presentation-]

[22] Refers to the very pure level [only]. ${ }^{57}$

In this context, using the example

Of the body of a sovereign king drawn as a picture, 58

[Maitreya] clearly proclaimed

53 Mahāyānasamgraha, Theg pa chen po bsdus pa, D4048, sems tsam, ri, 1a-43a.

54 Abhidharmasamuccaya, Chos mngon pa kun las btus pa, D4053, sems tsam, li, 1a$117 \mathrm{a}$.

55 Guhyasamāja, Gsang ba 'dus pa; the full title: Sarvatathāgatakāyavākcittarahasyaguh yasamājanāmamahākalparāja, De bzhin gshegs pa thams cad kyi sku gsung thugs kyi gsang chen gsang ba 'dus pa zhes bya ba brtag pa' i rgyal po chen po, D443, rgyud, ca, 90a-157b.

56 Kālacakra; the full title: Paramādibuddhoddhritaśrīkālacakranāmatantrarājā, Mchog gi dang po' $i$ sangs rgyas las phyung ba rgyud kyi rgyal po dpal dus kyi 'khor lo zhes bya ba, D0362, rgyud, ka 22b-128b.

57 See the Explanation passage immediately preceding verse 84 (A Study, 258).

58 Sublime Continuum, verses 88-92. 
[23] That śrāvakas, pratyekabuddhas, etc., ${ }^{59}$ do not have the emptiness endowed with

The supreme of all aspects.

Using the examples of the sun and rays of light, ${ }^{60}$

[Maitreya also] taught that

[24] Until one has manifested

[The state of] a perfect buddha, s/he does not have

The essence inseparable from all positive qualities.

In this context, there is no chance to explain

[25] Those of great desires, [heretics,] śrāvakas and pratyekabuddhas

Even as [mere] bases of the [buddha-]essence,

Let alone as [actually] realizating the [buddha-]essence.

1.2.2.1.2. The second way of explaining [the buddha-essence: by the nine examples and their meanings].

[26] At the beginning of the explanation of the intent

Of [the Buddha] teaching in the sūtras

That all sentient beings have the buddha-essence,

The basis of intent is divided into three types (rnam pa).

[27] The three are the "dharma-body,"

"Suchness," and "lineage."61

The first one is of two types due to the division into

The dharma-sphere free from adventitious stains

[28] And what is causally concordant with it (nișyanda, rgyu mthun).

What is causally concordant [with it] is [also] of two types due to the division into

The profound and extensive scriptural teachings [of the Buddha]. ${ }^{62}$

The suchness is described

[29] Only as the natural purity. ${ }^{63}$ /127/

The lineage is of two types due to the division into

The naturally abiding lineage and the developing lineage.

In the second one, there are three types of ability

[30] To produce the three [buddha-]bodies (sku gsum po, trikāya). ${ }^{64}$

Thus, [these] are the five aspects [related to the lineage].

In that [context], the dharma-body is the actual [buddha-]essence.

The suchness is of two types (rnam pa):

[31] That which is and that which is not the buddha-essence.

The lineage is [merely] imputed as the result from the cause (rgyu las 'bras bur btags).

The dharma-body [pertains] to perfect buddhas,

And radiates ('phro ba, spharana) also to all sentient beings.

59 I.e., the four individuals discussed in the Sublime Continuum, verses 32-33, with the subsequent commentary by the Explanation: those with great desires ('dod chen, icchantika), heretics (mu stegs, tīrthika), śravakas and pratyekabuddhas.

60 Sublime Continuum, verses 93-94.

61 Ibid, verse 144.

62 Ibid, verse 145.

63 Ibid, verse 148.

64 Ibid, verses 149-150. 
[32] The suchness [pertains] to all phenomena.

The lineage is the property (chos, dharma) of sentient beings exclusively.

The suchness is of three types:

[The suchness] present in buddhas, ārya bodhisattvas,

[33] And the four [types of] individuals:

Those of great desires, heretics, etc.

The first [type] is the fully complete dharma-body.

The second one is a mere part of the dharma-body.

[34] The third one is not even a mere part of the dharma-body,

And therefore is not suitable to be the [buddha-]essence.

In brief, all Mahāyāna āryas

Are possessors of the sugata-essence.

[35] Because sentient beings other than them

[Do] have the suchness and the lineage,

Those [beings] are [merely] imputed as possessors of the sugata-essence.

Thus, all sentient beings are taught

[36] To be possessors of the buddha-essence

By way of the three [elements of the interpretive teachings]: the basis of intent,

The purpose, and the damage to the explicit [teaching].

The basis of intent is the suchness with stains (dri bcas de bzhin nyid, samalātathatā).

[37] The purpose is for the sake of eliminating the five faults (skyon, doșa). ${ }^{65}$

The valid cognition damaging the explicit [teaching]

Will be presented here [as it is] held within the text[ual words] (gzhung gis zin pa).

The dharma-sphere of the four [types of] individuals

[38] Is not the sugata-essence, because [in general, those individuals]

Have fallen into the view of the transitory collection,

[Explicitly enjoy wrongs,] and [their] minds are distracted from emptiness. ${ }^{66}$

What is the connection [between the elements] of that [reasoning]?

[39] [It is inferred] from [the features of those] sentient beings

Whose dharma-sphere has become the sugata-essence,

Because [they] generated in their mental continuum the antidotes (gnyen po, pratipakșa)

That eliminate those three detriments (nyes pa). ${ }^{67}$

65 They are listed and explained in the first chapter of the Sublime Continuum, verses 157-165: (1) a discouraged mind unable to produce bodhicitta, (2) despising as lowly those beings who did not generate bodhicitta, (3) grasping at what is not real: artificial and adventitious faults of sentient beings, (4) deprecating real qualities: the positive qualities with the pure mode of subsistence, and (5) such an excessive attachment to self that one cannot love others equally to oneself.

66 See the next note.

67 They are discussed in the Explanation (A Study, 302-303). These three are the faults of those who have fallen into the view of transitory collection ('jig tshogs la lta bar lhung ba), explicitly enjoy wrongs (pnyin ci log la mngon pardga' ba), and have minds distracted from emptiness (stong pa nyid las sems rnam par gyengs pa). 
[40] Therefore, as soon as there have been produced /128/

The aspiration towards Doctrine and other of the four [antidotes] ${ }^{68}$

That eliminate the four obscurations (sgrib pa, àvarana)

That obscure the sugata-essence, ${ }^{69}$

[41] The individual who is the basis [of those antidotes]

Is described as the possessor of the buddha-essence. ${ }^{70}$

Also, the dharma-sphere of the four [types of] individuals

Is not the [buddha-]essence,

[42] Because it does not have the [first] five [of the eight] meanings [dealt with in the ten types of Presentations discussed above]: entity, cause, result, action, and possession.

It does not have the meaning of entity,

Because of not [having] the power (mthu, prabhāva) and not being moistened with compassion (snying rje, karuñā).

[43] The meaning of the cause is [also] incomplete,

Because it does not have the four causes

That purify the four obscurations. ${ }^{71}$

It does not have the meaning of the result either,

[44] Because it does not have the antidotes

To expel the four types of erroneous [views] (phyin ci log, viparyāsa)

Regarding the dharma-body. ${ }^{72}$

The meaning of function is also incomplete,

[45] Because it is not ascertained that it [i.e. dharma-sphere of the four individuals]

Has the functions produced from

The awakening of the potential of the lineage

By the conditions of the four wheels ('khor po bzhi, catuścakra). ${ }^{73}$

68 The four antidotes are the aspiration towards the Mahāyāna Doctrine (māyānadharmādhimukti, theg pa chen po'i chos la), perfection of wisdom (prjnāparamitā, shes rab kyi pha rol tu phyin pa), meditative stabilization (samādhi, ting nge 'dzin), and great compassion (mahākaruṇā, snying rje chen po). See Explanation (A Study, 205-206).

69 These four are: hatred towards the Mahāyāna Doctrine (mahāyānadharmapratigha, theg pa chen po'i chos la sdang ba), the view of self (ätmadarśana, bdag tu lta ba), fear of the sufferings (duhkha-bhìrutva, sdug bsngal gyis 'jigs pa), and lack of concern for the welfare of sentient beings (sattvärtha-nirapekșatā, sems can gyi don mi ltos pa). See Explanation (A Study, 205-206).

70 Enjoyment Ocean of Scriptural Statements and Reasoning, vol. 1, 498, explains that the initial boundary of these causes of essence (snying po'i rgyu) is the first bodhisattva-ground.

71 I.e., the four antidotes to the four obscurations, both mentioned above.

72 These antidotes (pratipakșa, gnyen po) are described as purity (śubha, gtsang ba), self (ātman, bdag), bliss (sukha, bde ba), and permanence (nitya, rtag pa) that are the features of the dharma-body. They are the opposites of impurity, no-self, suffering, and impermanence that are erroneously ascribed to the dharma-body. See the Sublime Continuum, verses 35-36 with the subsequent commentary in the Explanation (A Study, 207-208).

73 Asanga's Explanation mentions the first of the four: relying on a holy person (satpurușa, skyes bu dam pa). The other three are either dwelling in a favorable place, offering aspirational prayers, and accumulating merits, or-and Takasaki sees them as most suitable-to approach, attend, and accept the teaching, to contemplate the meaning of the doctrine, and to practice according to the teaching (see A Study on the Ratnagotravibhāga, 223). Also, see verse 73 of the Essence of Sütras and Tantras. 
[46] Otherwise, those with wrong cravings

Also would have those functions. ${ }^{74}$

The meaning of possession is also incomplete,

Because it does not possess the three:

[47] The dharma-body, the cause of the primordial mind of the Victor,

And the great compassion; ${ }^{75}$

And also because it does not have even mere parts of

The three positive qualities: "the five clairvoyances" (mngon shes lnga, pañābhijñā),

[48] "The primordial mind [in which contaminations are exhausted]" (zag pa zad pa's ye shes āsravakșayajñāna),

And "the exhaustion of contaminations" (zag pa zad pa, āsravakșaya) [itself], ${ }^{76}$

Set aside consideration of [its] inseparability [from them].

In brief, the Sublime Continuum of Mahāyāna

[49] Does not teach that all sentient beings

Have even a mere [buddha-]essence,

Set aside consideration [of them] having the essence

Ornamented with the major and minor marks [of a buddha].

[50] This is because the basis of intent, the purpose,

And the damage to the explicit [teaching]

Of their existence in those [ordinary beings] -

[All] the three are held within the words of the text itself.

[51] Some [thinkers] say that the Sublime Continuum of Mahāyanna

[Has to be] commented upon as [a scripture of] interpretive meaning (drang don, neyārtha).

No commentators who would explain the Sublime Continuum treatise As [a scripture of] interpretive meaning ever appeared before [them]. 1.2.2.2.

[52] Presentation [of opinions] /129/

Of the two tradition founders from the Land of Āryas,

And different types of opinions of others.

1.2.2.2.1.

1.2.2.2.1.1.

In the Praise to the Dharma-Sphere,

[53] Ārya Nāgārjuna taught that

Suchness exists in all sentient beings.

With the example of gradually increasing

Parts of the new moon, [he] explained that

74 See Sublime Continuum, verse 40, with the subsequent commentary by Asanga. These functions are described as discouragement with sufferings on the one hand, and wishing, striving, and aspiring to achieve nirvāna on the other.

75 Sublime Continuum, verse 43.

76 Sublime Continuum, verse 44 followed by Asañga's commentary. 
[54] The dharma-body exists from the Utmost Joy ground Through to the buddha-ground.

1.2.2.2.1.2.

[The discussion of] the tradition of ārya Asanga

Has an actual [presentation] and [an explanation of] the intend[ed meaning].

1.2.2.2.1.2.1.

[55] In the commentary [on the Sublime Continuum] that he composed,

With the example of the sun shining in the sky

Amidst the clouds and in the cloudless sky,

[Asanga] explained the boundaries (sa mtshams, s ìma) of

[56] [And] the way of seeing the essence from

The ground of the Utmost Joy through to the buddha-ground.

Objection: This is just the way of seeing the essence.

[It does] not [indicate] the boundaries

[57] Of existence of the actual essence.

Answer: [You] will learn [the right interpretation]

By analyzing what the meaning of what is seen (mthong bya) refers to.

If what is seen is just a natural purity,

[58] Then why do even āryas on the ten [bodhisattva] grounds

Not see the essence completely?

Also, with this [position, you will incur] five detriments of contradicting

The scriptural pronouncements of foremost venerable [Maitreya]:

[59] 1) If a mere natural purity were the essence,

There would be no connection between

The question regarding the clouds, etc.,

And its answer. ${ }^{77}$

[60] 2) All sentient beings[—not just the Mahāyāna āryas-] who have entered the path

Will become the Jewel of Spiritual Community (dge 'dun dkon mchog, samgharatna),

Because [according to you,] they are

Sentient beings who have the sugata-essence.

[61] Otherwise, how would [you] explain the Jewel of Spiritual Community also

As [one of the seven] vajra-topics (rdo rje'i gnas, vajrapada)? ${ }^{78}$

77 Sublime Continuum, starting verse 156.

78 The seven vajra-topics are the Buddha (sangs rgyas), Doctrine (chos, dharma), Spiritual Community (dge 'dun, samgha), element (khams, dhātu), enlightenment (byang chub, bodhi), positive qualities (yon tan, guna), and activities (phrin las, karman). 
3) It will follow that the order of the seven topics

Also will necessarily be non-existent. ${ }^{79}$

[62] 4) If the suchness with stains

Were an actual essence,

It will contradict the two verses:

"[There is nothing] to eliminate here ...,"etc. ${ }^{80} / 130 /$

[63] This is because that textual passage presented

The dharma-body free from adventitious stains [as] the essence.

In the Essence Sütra, it is taught that

When one part of stains of the element

[64] Has been purified by the stages of the three Wheels of Doctrine (chos 'khor, dharmacakra),

One enters the sphere of activity (spyod yul) of the buddhas. ${ }^{81}$

(5) Question: Then why [is it said that]

Ārya Sons of Victors [i.e., ārya bodhisattvas] see the essence

[65] Even in places of animal rebirth? ${ }^{82}$

Answer: When one sees

One part of one's own reality

Being pure of stains,

[66] S/he sees all sentient beings also in a similar way. ${ }^{83}$

This is described as seeing all sentient beings

As possessors of the buddha-esence,

As the realization of the dharma-sphere as ubiquitous,

[67] And as the realization of the multiplicity (ji snyed, yāvat) [i.e., conventional phenomena]. ${ }^{84}$

Otherwise, if it were a description of the [way of] seeing

The naturally pure reality [i.e., the mode (ji lta, yathā) or the ultimate truth],

Then what would be the way of seeing the multiplicity?

1.2.2.2.1.2.2.

79 In the Enjoyment Ocean of Scriptural Statements and Reasoning, vol. 1, 503, Sākya Mchog Ldan explains that the order of the seven topics is the cause-result order, not the order of seeing them. (See the Opening the Doors of the Chest of Gems: Treatise Elucidating the Stages of the Path of the Five Doctrines of Maitreya (Byams chos lnga'i lam gyi rim pa gsal bar byed pa'i bstan bcos rin chen sgrom gyi sgo 'byed), vol. 11, 139, for the discussion of two possible orders of the seven topics.)

80 See the paper above.

81 tshe looks like a misspelling for so.

82 Sublime Continuum, verses 120-121.

83 Enjoyment Ocean of Scriptural Statements and Reasoning, vol. 1, 503 helps to clarify what "in the similar way" means: It is stated that the vision of bodhisattvas is born from the first ground, because from that time on, they realize the dharma-sphere as ubiquitous. Therefore, because the dharma-sphere is the basis of intent of the essence, there is no way but to give the name of "seeing the essence" to the seeing of the dharma-sphere. Otherwise-explains Śakya Mchog Ldan-if bodhisattva sees them as actually having the essence with inseparable powers, etc., it will follow that they do have the essence with inseparable powers, etc.

84 Sublime Continuum, verse 16. 
[68] Explanation of the intended meaning:

Therefore, [the term of] the sugata-essence

Expresses the sugata itself.

That [sugata] is also of two types: that [which refers to]

[69] The feature of abandonments (spangs pa, prahāna) and the feature of realizations (rtogs pa, adhigama).

\subsection{2.1}

The first one is also [of two types]:

The actual one and its similitudes (rjes mthun, anurūpa).

The similitudes are also of two types:

[70] The [state of] purification of stains of the element

By the aspiration towards the Doctrine and other of the four causes, and

The [state of] abandonment of the stains of afflictions

By the wisdoms of followers of the Lesser Vehicle [of śrāvakas and pratyekabuddhas].

[71] The first one is the actual [buddha-]essence.

The second one is not explained

Even as a mere basis of intent of the [buddha-]essence.

The nature with stains is taught to be

[72] The basis of intent of the sugata-essence

From the point of view of [this nature] being suitable

For separation from adventitious stains (blo bur gyi dri ma, àgantukamala).

But there is no clear explanation of [it] being the actual [sugata-] essence.

[73] At the time when the [five] faults have been destroyed with [the help of] the four wheels-

[So that] the potential of the lineage became awakened, And one part of stains of the element

Is eliminated by the aspiration towards the Doctrine

[74] And other of the four causes that purify stains-

At that time [this partial purity of adventitious stains]

Is posited as the actual sugata-essence.

1.2.2.2.1.2.2.2

[The sugata of] realizations is also of two types:

[75] The dharma-body and its similitudes.

The similitudes are also of two types: that which is distinguished

By the four causes, and that which is not.

The distinguished one is also of two types:

[76] That which is pure of corresponding stains, and that which is not.

Only the pure one is explained as the dharma-body

And the sugata-essence.

Therefore, there are two types of the buddha-essence: 
[77] Compounded and uncompounded.

[In this way, it] is divided into two:

[That with] the relative and [that with] the ultimate meaning.

[When it is] explained that [the essence]

[78] Is exclusively uncompounded, what is intended

Is that [natural purity] which exists in all sentient beings [but is not the actual essence].

The statement that [the sugata-essence] is only the ultimate truth

Belongs to the system of others, not to the textual system

[79] Of the foremost venerable Maitreya [followed by Asanga].

1.2.2.2.2.

Next is the presentation of different types of other [opinions].

In the texts of the śrāvaka schools,

There is no explanation of the buddha-essence.

[80] In the Cittamātra treatises,

The uncontaminated seeds (zag med sa bon) of the basis-of-all (kun gzhi, àlaya)

Are viewed as the sugata-essence.

There also exists a statement that [it] is ornamented with the major and minor marks [of a buddha].

[81] No contradiction between the three final vehicles (mthar thug theg pa gsum)

And [the presence of the stainless seeds] is accepted in this [system]. The statement that the basis-of-all [itself] is asserted as the essence Is not [based on] the Cittamātra scriptures.

[82] Fearless Candrakýrti, having refuted

That meaning [of the tathāgata-essence],

Explained the Middle Wheel's freedom from elaborations itself As the basis of intent of [teaching] the essence.

[83] Victor's Son [Rngog] Blo ldan shes rab,

Having imputed terminology of the causal,

Natural, and resultant essence to the three-

The lineage, suchness, and

[84] Dharma-body in the same order,

Asserted that all sentient beings are

Possessors of the buddha-essence.

There are some [thinkers, who]

[85] Having subdivided into the two truths

Each knowable as well, say that

What is the ultimate truth's part (cha)

Is the buddha-essence. /132/ 
[86] [They] assert that "the buddha's dharma-body

Actually abiding in all sentient beings" also is the intent of

The bodhisattva commentaries ${ }^{85}$ and the Sublime Continuum.

Fearless Great Paṇdit of Sa skya, ${ }^{86}$

[87] Having refuted [the view that] the two-

The lineage and the dharma-sphere are the essence,

Asserted that only the dharma-body

Is the buddha-essence.

[88] What is [his] reasoning [supporting] that?

The dharma-sphere is not the essence.

Were it so, it would follow that all knowables

Are also possessors of the essence.

[89] In that case, [such an assertion] would be equal

To those of the followers of Vedas (rig pa byed pa) who assert that

All external and internal phenomena are pervaded by purușa (skyes bu).

Objection: It is not similar, [because] others impute it as truth,

[90] [While] here [it is viewed as] free from elaborations.

Answer: [This is wrong,] because the freedom from elaborations [pervading all phenomena] is not a virtue (dge ba, kuśala) [while you assert that the essence is a virtue]. ${ }^{87}$

Also, if [you] grasp at the freedom from elaborations (spros bral, aprapañca) as a sign (mtshan ma, nimitta),

Saying that it is the essence, then [it will be turned into] a true thing (bden dngos),

[91] And the lack of elaborations will be turned into [yet another] elaboration.

Objection: The element (khams, dhātu) also is the [buddha-]essence,

Answer: [This is wrong as well:] because [the element] has stains, It is the element of sentient beings, not the buddha-essence.

85 These are the three commentaries written by ārya bodhisattvas: Pundarīka's Stainless Light Commentary (Vimalaprabhānāmamūlatantrānusārinīdvādaśasāhasrikālaghukālacakratantrarājaīkā, Bsdus pa'i rgyud kyi rgyal po dus kyi 'khor lo'i 'grel bshad rtsa ba'i rgyud kyi rjes su 'jug pa stong phrag bcu pa bcu gnyis pa dri ma med pa'i 'od ces bya ba). D1347, rgyud 'grel, tha, 107b-da, 297a; Commentary on the "Wheel of Time Tantra," Vajragarbha's Extensive Commentary on the "Condensed Meaning of the Hevajra Tantra" (Hevajrapindārthațīka gyi rgya cher 'grel pa, D1180, ka, 1-126a), Vajrapāni's Meaning Commentary on the Cakrasamvara Tantra (Lakșābhidhanāduddhṛtalaghutantrapiṇ̣̂ärthavivaraṇa, Mngon par brjod pa 'bum pa las phyung ba nyung ngu'i rgyud kyi bsdus pa'i don rnam par bshad pa, D1402, ba, 78b-141a).

86 I.e. Sa skya Pandita. Verses 86-97 summarize Śākya Mchog Ldan's understanding of Sa skya Pandita's interpretation of the buddha-essence in the latter's Clear Differentiation of the Three Codes, concentrating primarily on passages 121-132 of its first chapter. I am following the numbering provided in Jared Douglas Rhoton (trans.), A Clear Differentiation of the Three Codes: Essential Distinctions among the Individual Liberation, Mahāyāna, and Tantric Systems (Albany, New York: State University of New York Press, 2002). Notice that I translate such terms as dharmadhātu, etc., differently from Rhoton.

87 The discussion of the buddha-essence starts in passage 59 of the Clear Differentiation of the Three Codes, where Sa skya Pandita addresses the statement that the buddha essence is a virtue. 
[92] Objection: [The buddha-essence] is a non-thing (dngos po med, $a b h \bar{a} v a$ ) and is free from elaborations.

Answer: [This is] also [incorrect:] because [this non-thing and freedom from elaborations as you understand them]

Do not have inseparable positive qualities, [they can] not be [viewed as] the buddha-essence.

This is because the powers and all the other positive qualities

[93] [Of the buddha-essence do] have elaborations.

The freedom from elaborations is also of two [types]:

A non-affirming negation and an affirming negation.

The first one is an actual essence.

[94] Nevertheless, because both

Cyclic existence ('khor ba, saṃsāra) and nirvāna originate from it,

It is posited as the essence of [them] both.

Furthermore, from the point of view of having [adventitious] stains,

[95] [This first type of freedom from elaborations] is the actual buddha essence.

From the point of view of being naturally pure,

It is [merely] imputed as the buddha-essence.

Therefore, both the element and a mere dharma-sphere

[96] Are not asserted as the essence.

Upon that [analysis, Sa skya Paṇdita] /133/

Asserted the buddha-essence as the dharma-body,

[Described as] some buddha-dharmas (sangs rgyas chos)

[97] That are cast in remainder of negation

Of all elaborations imputed by minds grasping at signs.

In this way, [I have] clearly described

What the essence explained in the Perfection Vehicle is,

[98] [Having] acquired [this understanding]

Through [the teachings of my] virtuous friends [i.e. teachers] and [my own] discernment.

2.

Explanation of [the buddha-essence in] the Mantra system.

The essence taught in the lower Tantras (rgyud sde 'og ma)

[99] Is in agreement with that of the Perfection [Vehicle].

In the highest of all Yogas [i.e. the Highest Yoga Tantra (bla med kyi rgyud, anuttarayogatantra)],

The uncontaminated (zag med, anāsrava) great bliss (bde ba chen po, mahāsukha)

That totally transcends all elaborations

[100] [Is taught to be] the sugata-essence,

The truth of the ultimate meaning.

Its synonyms are:

"Emptiness endowed with the supreme of all aspects,"

[101] "Primordial mind of union" (zung du 'jug pa'i ye shes),

"Natural Hevajra" (rang bzhin dgyes pa rdo rje), 
"Vajra-being" (rdo rje sems dpa, vajrasattva),

"Primordial mind of dharma-sphere" (chos kyi dbyings kyi ye shes, dharmadhatujñāna),

[102] "Body of entityness" (ngo bo nyid kyi sku, svābhāvikakāya),

"Unchanging great bliss" ('gyur med bde ba chen po),

"Heruka of definitive meaning" (nges pa'i don gyi heruka),

And also "buddha-essence."

[103] It has two divisions:

[The primordial mind of] the innate nature (rang bzhin lhan cig skyes pa) and

The primordial mind of innate bliss (bde chen lhan skyes ye shes).

The first one [pervades] all inanimate and animate [phenomena],

[104] The second one-all embodied beings.

[The teaching stating that] 'all those subjects

Are possessors of the buddha-essence'

Is the secret of secrets acquired from

[105] Observances [instructed by] the guru, proper reliance on the method,

And the four empowerments (dbang, abhișeka).

If [this secret] is disclosed in that way to sentient beings who have not been

Brought to ripening by those empowerments, a [tantric] downfall will be committed.

[106] Even if followers of the Perfection Vehicle

Who have not entered this supreme Vehicle [of the Highest Yoga Tantra]

Were [trying] to hold to the thesis [dam bca'] that [such buddha-essence] pervades all

Inanimate and animate [phenomena, it would be] neither necessary nor possible.

[107] In that [Highest Yoga Tantra] three [types of] essence [are taught:

Those related to] the divisions of the basis, path, and result.

2.1 .

Because the result is the actual buddha, /134/

There is no need to raise doubts about [its being the actual] essence.

[108] It is also of two types [that are related] to

The dharma-body (chos sku, dharmakāya) and the form-body (gzugs sku, rūpakāya) divisions.

Although in the Perfection Vehicle,

The form-body is explained as a relative truth,

[109] Here, it is [explained as] the truth of the ultimate meaning,

Because it is [viewed as] the body of primordial mind (ye shes kyi sku, jñānakāya).

\section{2 .}


On the level of the path, there are two types of the essence

Due to the divisions of the Two Stages (rim pa gnyis, divikrama).

2.2.1.

[110] The primordial mind of the Perfection Stage (rdzogs pa'i rim pa, sampannakrama)

Is the [actual] tathāgata-essence,

And the actual truth of the ultimate meaning.

2.2.2.

The primordial mind of the Generation Stage (bskyed pa'i rim $p a$, utpannakrama)

[111] [Also] is the actual sugata-essence.

Why? Because of not deceiving by connection ('brel bas mi bslu)

At the time of engaging [in practice] with adherence (zhen pa). ${ }^{88}$

[Nevertheless, it is] not the actual ultimate truth,

[112] Because of being imputed by concepts. It is a concordant ultimate

(mthun pa'i don dam, ${ }^{89}$ samānaparamārtha).

Why? Because it is an object

Yogis set in meditative equipoise on.

[113] This is why in the Secret Assembly,

It is taught to be a relative truth.

[But] there is no doubt that when that illusory body (sgyu ma'i sku)

Has also transformed (gnas gyur) into the body of primordial mind,

[114] [It becomes] the truth of the ultimate meaning.

2.3.

On the level of the basis, the essence is also of two types

Due to the divisions into the actual and imputed one.

2.3.1.

The first one:

[115] Whatever appears in the face (ngor) of the primordial mind

Of a yogin of the Supreme Vehicle-

All [of it] is pervaded by the actual buddha-essence.

Why? Because all of those [phenomena]

[116] Are of one taste within [that] very

Primordial mind of great bliss (bde chen gyi ye shes) of the yogin.

Whatever appears as an object of consciousness

Of a person with impure mind-

[117] All of that is pervaded

By the union of clarity and emptiness (gsal stong zung du 'jug pa).

88 When a practitioner of the Generation Stage who is habituating with seeing oneself as an enlightened deity, engages with adherence to that visualization, this practice is not deceiving by connection with reality. This is because the practitioner wishes his own reality to be a buddha, and that reality is established as such. For details, see the Golden Spoon, vol.6, 530, also the Answers to Objections to the "Establishment of the Original Buddha" Text, vol.13, 146.

89 Text: 'thun. 
[That union is merely] imputed as the buddha-essence.

Otherwise, [were it the actual buddha-essence,] it would follow that

[118] [It is] the actual primordial mind of great bliss.

If it were [possible] to see the primordial mind of great bliss

Without having entered the Supreme Vehicle [of the Highest Yoga Tantra],

Then everybody would have [already] attained the Supreme Vehicle.

[119] [Also, when it is] stated that "In the non-artificial body (bcos min lus), within the naturally established mandalas (rang bzhin gyis grub pa'i dkyil 'khor),

There actually dwell the buddha-bodies /135/

Endowed with the major and minor marks,"

[120] On the level of the cause and the path,

What [else if not empowerments can be] meant as the means

Of purification of stains of the three: the body, speech, and mind?

Stating that the mandala of accomplishment (grub pa'i dkyil 'khor)

[121] Dwells in the beings who were not brought to ripening

By the empowerments is not the Mantra system.

Were it so, [such beings] would be buddhas of the Mantra [system]

Who were not brought to ripening by the empowerments.

[122] Therefore, the clarity-emptiness (gsal stong)

Is the essence of both cyclic existence and buddhahood. The union conjoined with the method (thabs kyis zin pa) [of the Mantra system]

Is the actual buddha-essence

[123] And is [merely] imputed as the essence of cyclic existence.

The union which is not conjoined with the method

Is the actual essence of cyclic existence

And is [merely] imputed as the buddha-essence.

[124] Therefore, [the union] conjoined with the method

Is not smeared by phenomena of cyclic existence.

But even [when the union is] separated from the method,

It is called the "inseparability of cyclic existence and nirvāna" ('khor 'das dbyer med, saṃsāranirvāṇāsaṃbheda),

[125] Because the union of clarity and emptiness [itself can] not be split apart.

In brief, when the Path of Seeing [of Tantra] has been attained,

In the face of vision (gzigs ngor) [of the mind on that path,]

All inanimate and animate [phenomena] are pervaded by the buddha essence,

[126] Because the primordial mind of the meaning (don gyi ye shes) has been acquired.

Due to [all] those, one should not blend into one

The two [distinct] traditions of Mahāyāna,

Because in the Perfection [Vehicle], the establishment of the result 
[127] On the level of the cause is refuted,

And because in the Unsurpassed Vehicle, [on the contrary,]

The result is made into the path (lam du byed pa).

By the white virtues

[128] Generated from such explanation,

Let all migrating beings, [my] mothers,

Learn the profound meaning of the definitive meaning!

This [explanatory] way emerged today

[129] From the glory of the throat Of Rje Btsun Dgyes Pa'i Bshes Gnyen,

Who is taking rest in the wish-fulfilling ocean of wealth /136/

Of king Bkra Shis Mgon and his relatives.

[130] Let all wishes without exception

Of the ruler of men together with [his] ministers

Be perfectly fulfilled in accordance with

The textual systems of religion and politics,

[131] And let [them] have no external opponents,

Let all [their] subjects [live in] happiness,

And let [them enjoy their] exalted status forever!

This "Essence of Sūtras and Tantras": Explanation of the Buddha-Essence was composed with a respectful mind at the request of Rkong Ston Mgon Po Rgyal Mtshan by the learning-holder and fully ordained monk from the Central Land, glorious Śakya Mchog Ldan Dri Med Legs Pa'i Blo on the 10th day of the first half of the second lunar month of the wood-malehorse year (1474) called "victorious, in the great Thub bstan dar rgyas gling monastery in Mnga” Ris Smad. Śubham 90

\section{The Sun Unseen Before: Definitive Meaning of the "Sublime Continuum" Treatise}

Svasti!

I prostrate to the sugata, the perfect buddha,

Not accomplished by anyone, accomplished primordially,

Praised, venerated, and eulogized

[As] the "buddha-essence"!

It is difficult to realize its meaning entirely.

Though it is difficult, if explained upon purification (sbyangs), [it can be] known.

In order to benefit wise ones,

I will explain it irreversibly. Listen to this! ${ }^{91}$

90 This Sanskrit word translates as "prosperity".

91 Thise verse cannot be fully appreciated unless read in Tibetan: the last syllable of every preceding line is identical to the first syllable of every following line. 
After [these stanzas of] worship and promise to compose [the text], I proceed to the main body of the text, that focuses on three issues: the main topic of the Sublime Continuum treatise; in what way such [buddhaessence] abides in what place (gnas); becoming learned in all knowables being contained in the modes of the two truths.

1. The main Topic of the Sublime Continuum Treatise.

[It is] the primordial mind of the dharma-sphere that, from the beginning, intrinsically has all the positive qualities of powers, and so on.

2. In What Place It Abides.

[It abides in] all buddhas and sentient beings.

[3. Becoming Learned in All Knowables Being Contained in the Modes of the Two Truths.]

Both the abode (gnas) and the abider (gnas pa) are also of two types each: relative and ultimate.

The relative essence is a possessor of newly acquired positive qualities. The ultimate essence is a possessor of primordially established positive qualities.

The relative sentient beings are [sentient beings of] six types. The ultimate sentient being is their mode of abiding (gnas tshul): the primordial mind of dharma-sphere.

The relative buddha is that which appears to cognitions (rnam rig, vijñapti) of others as the aspects of the body, speech, and mind of the formbody [of the buddha].

The ultimate essence, the ultimate buddha, and the ultimate sentient being come down to the same meaning (don gcig la 'du ba), because if that sole dharma-sphere is naturally pure of all its objects of abandonment, it [also] has to have all positive qualities naturally accomplished.

The relative essence and the relative buddha come down to the same meaning, because they have to be identified as follows: that which appears in appearances of others (gzhan snang) ${ }^{92}$ as having all faults extinguished and all positive qualities perfected.

That relative essence does not exist in all relative sentient beings, because even on the relative level, the essence is not identified as having obscurations, while sentient beings are opposite of that [i.e., necessarily have obscurations].

The ultimate essence pervades both ultimate buddhas and ultimate sentient beings, because all three come down to the same meaning.

Question: When there emerged [such] discordant identifications of the essence and discordant ways of explaining the basis on which that [essence] abides, [you] have to clearly explain the presentations of:

- what the identification of the abider, the essence is; 
- where it [abides]: in buddhas or sentient beings, [i.e.,] the features of its abode; /116/

- at what time it exists or does not exist as a pervader (khyab byed).

Answer: When [the teaching that] all sentient beings are pervaded by the essence is explained as having [a veiled] intent,

- the identification of the essence is made from the point of view of the relative [essence]: the one with faults newly abandoned and positive qualities newly acquired;

- the abode [of that essence] is in general all sentient beings without even a slightest partiality (phyogs re tsam yang med pa): ordinary beings;

- the time: when the presentation of the essence is determined by listening and thinking.

- the subject (yul can, vișayin) [of such essence] should be posited from the point of view of consciousness (rnam shes, jñāna). This is because neither of the two identifications of the essence is seen by consciousness directly (mngon sum $d u$ ). ${ }^{93}$

Such essence is not explained as imputed (btags pa ba) either. Were it explained so, the intent of teaching that the essence pervades all sentient beings would not be established.

On the other hand, when it is explained [and literally accepted] that the essence pervades everyone (thams cad),

- [the essence is] identified as the naturally pure buddha (rang bzhin rnam dag gi sangs rgyas): the one that never needs elimination and positing of faults and positive qualities [respectively];

- [the abode] in which it abides is all ultimate sentient beings and the ultimate buddha;

- the time: [starting] from [the moment when] the primordial mind arisen from meditation experiencing at least one part of the essence has been manifested.

- the subject is ascertained as the primordial mind exclusively; it is of three types due to the division into the basis, path, and result.

The mode of abiding (gnas tshul) of the ultimate essence does not have the division into the basis and result. Nevertheless, the division into [the essence with] the positive qualities perfected or not perfected has originated from the mode of seeing by consciousness (rnam shes mthong tshul).

Also, [the teaching that] the ultimate sentient beings are pervaded by the essence does not have to be explained as having [a veiled] intent, because

- the ultimate essence and the ultimate sentient being come down to the same meaning;

93 The relative essence is not realized by consciousness directly because it is an object of conceptual consciousness only, while the ultimate essence is not an object of consciousness at all. It is realized only by the primordial mind. 
- since it is explained as the ultimate self (dam pa'i bdag, paramātma), the way of explaining it contradicts that of heretics' self;

- although this ultimate essence is accepted as the ultimate self, nevertheless, the relative essence is not accepted as that [ultimate self]. /117/

On the other hand, the teaching that all sentient beings are pervaded by the relative essence has to be interpreted as having [a veiled] intent, because

- as the basis of intent, the ultimate essence is intended;

- the purpose is the abandonment of the five faults;

- the damage to the explicit [teaching derives from the fact that the features of] abandonment of all obscurations and knowledge of all knowables are not present in all relative sentient beings.

Objection: The division of the essence on [the basis of] the two truths is not taught in the scriptural statements.

Answer: It is not [true], because [both types of essence were taught by the Sublime Continuum]. The relative essence was explained by: "Because the body of a perfect buddha emanates ..."94 and by [the passages on] the developing lineage. ${ }^{95}$ The ultimate essence was explained by [the passages on] suchness ${ }^{96}$ and the naturally abiding lineage. ${ }^{97}$ From among the ten presentations, ${ }^{98}$ the ultimate essence was explained by [the passages on] the meaning of the entity and the meaning of unchangeability, while the relative essence was explained by the textual passages explaining inseparability of positive qualities. If [I were to] explain [these] and other explanatory ways extensively [there would be] much [more to add].

In the unique (rang rkang) [teachings] of the Pronouncement of the Middle Wheel, presentations of the ultimate sentient beings and ultimate essence are not explained, and because of the objective (dgos pa) [of those teachings, such ultimate essence is] explained as interpretive. In that context, [the essence and sentient beings] do not pass beyond the relative essence and [relative] sentient beings.

In the unique [teachings] of the Pronouncement of the Third Wheel also, it is explained that the relative essence fulfills the role of the essence conventionally. Nevertheless, it is not asserted even conventionally that it pervades all sentient beings. This is because in that context, the presentation of the five paths (lam lnga, pañcamārga) and the ten grounds (sa bcu, daśabhūmi) has to be asserted as gradual.

94 Sublime Continuum, first line of verse 28. The whole verse reads: Because the body of a perfect buddha emanates, // Because suchness is indifferentiable, // And because of having lineage, all embodied beings // Always have the buddha-essence.

95 Ibid, in verses 149-152.

96 Ibid, verse 148.

97 Ibid, in verses 149-152.

98 For the list and corresponding verse numbers, see note 33 . 
Also, in the Third Wheel, the ultimate essence is explained literally as permanent, stable, and eternal (g.yung drung, śáśvatā). But that is also done from the point of view of [its] continuum (rgyun). Otherwise, [it should] be [understood as] impermanent, precisely because of having an immediately preceding condition [deriving] from [its previous] moment (skad cig las ni de ma thag pa'i rkyen can). [This is similar to] the extensive explanation in the Mother [i.e. Perfection of Wisdom sūtras]: "If form were the subject of (chos can, dharmin) [being] permanent, stable, everlasting, and unchanging ( $m i$ 'gyur ba, avikāra), ..." etc., that was also intended with the ultimate form, etc., [as its referent]. /118/

Nevertheless, the Middle and the Last Wheels are not asserted as contradictory, because it is precisely from the Third Wheel that there derives the mode of incorporating into experience that very [meaning which] has been determined by listening and thinking [taught] in the Middle Wheel.

In brief, in the scriptures of sutras, there is clearly present the division of the essence into two due to the distinctions of the natural purity and purity from adventitious [defilements]. In that context, by the teaching that the essence with complete characteristics of purity from adventitious [defilements] pervades sentient beings, the fivefold purpose is accomplished. Nevertheless, because the damage to the explicit [teaching] is observed, that [teaching has] an interpretive meaning.

[On the other hand,] the teaching that the naturally pure essence pervades all ultimate sentient beings is only literal: because [the statements that] the mind is luminous by nature and stains have never existed from the beginning are ascertained in any Mahāyāna sūtras as exclusively literal (sgra ji bzhin pa, yathāruta), no valid cognition damaging the explicit [teaching of] that [ultimate essence] pervading those [ultimate beings] is explained, and no identification of the ultimate essence other than the natural purity is observed either.

When [it] is explained in such a way, [it becomes clear that]

- there are no other phenomena apart from the primordial mind of dharma-sphere,

- the realization of exclusively that very primordial mind as the mode of abiding of phenomena is the way of realizing the [ultimate] mode (ji ita, yathā) by the buddha,

- seeing that all ultimate sentient beings are pervaded by the ultimate essence is the way of seeing multiplicity [ji snyed, yāvat] by the buddha,

[This is] clarified in the text itself.

Therefore, the seven topics taught by the treatise of the Sublime Continuum [should] be divided into the relative and the ultimate [topics each]; the first [type is posited] from [the point of view of] the mode of appearance to consciousness, while [the second type] is posited as the ultimate from [the point of view of] the mode of knowing by the primordial mind only. /119/ The vajra-topics are exclusively of the latter [type], precisely because the former [type] is relative. 
The division of the Three Jewels (dkon mchog gsum po, triratna) into two [types] is taught by one verse:

In order to [show the qualities of] the Teacher, the Doctrine, ... ${ }^{99}$ etc.

The division of the remaining four topics into two [types] is taught by one [more] verse:

Because of being pure and having afflictions, ... ${ }^{100}$

etc. This is because no debates appear [to be raised in the Sublime Continuum] regarding [the fact that,

- there emerged two explanations of suchness: as the one that has no stains, being naturally pure [of them], and as the one that has them;

- it is clear that enlightenment is [also taught to be of] two [types]: the naturally pure one and the one pure of adventitious [stains];

- positive qualities and functions are [also] divided into two: those which are present in a buddha's own mind and those which are [present in] appearances of others-disciples [of a budddha].

Some other [thinkers] say:

The identification of the essence as permanent, stable, etc., does not [refer to anything] other than the very pure level only, because what is described by such words as:

By uncontaminated compositional [actions], ...

[and]

[It is] without birth of the mental body [as well],

Because of being permanent. ${ }^{101}$

etc., cannot [refer] to [anything] other than the resultant level.

Some other [thinkers] say:

Permanence, stability, etc., are intended to [refer to] the mind's dharma-sphere, the non-affirming negation, because the positive qualities of powers, etc., cannot be explained as permanent, etc.

99 Sublime Continuum, verse 19. The whole verse reads: "In order to [show] the Teacher, the Doctrine, and learners, // The Three Refuges were posited // In terms of those of the three vehicles // And those devoted to the three observances."

100 Sublime Continuum, verse 25. The whole verse reads: "Because of being pure and having afflictions, // Because of having no afflictions and being purified, // Because of inseparable phenomena, // And because of spontaneity and non-conceptuality."

101 Sublime Continuum, in verses 80-81. The two verses read as follows: "[It is] without birth of the mental body [as well], // Because of being permanent. // It does not die with inconceivable // Transmigration, because of being stable. // It is not harmed by the sickness of // Subtle habitual tendencies, because of being quiescent. // Because of being eternal, [unaltered even] // By uncontaminated compositional [actions], it is without aging." 
[My] explanation of unfeasibility of [these two explanatory ways] has two parts: unfeasibility of the first explanatory way, and unfeasibility of the second explanatory way.

(1) By the words [of the Sublime Continuum]:

As it was before, so it is later, ... ${ }^{102}$

[etc.,] not only the essence on the level of the basis is explained as permanent and stable, but the essence on the level of the result [too] is explained as permanent and stable. Therefore, the essence of [both] the basis and the path also is established [as permanent and stable]. This is because it is not possible to explain that the ultimate essence on the three levels (dus gsum pa can) has even slightest dissimilar divisions by way of its entity. /120/

As for the relative essence, because there are explained dissimilar divisions of newly seeing the dharma-body, starting from the first [bodhisattva] ground till the buddha-ground, it is possible to explain the existence of dissimilar divisions [of the essence] by way of [its] positive qualities.

Yet, according to both ways of explaining the essence, what is described as [its] characteristics-permanence, stability, etc., are fully present [in both of its two types-the ultimate and the relative essence]. This is because both [types of essence] have never had any birth, death, and aging due to ${ }^{103}$ the ground of habitual tendencies of ignorance ( $m a$ rig bag chags kyi sa), apart from [having those tendencies as] that binds to cyclic existence ('khor bar'ching byed).

Question: Does it not have to be explained that childish beings (byis pa, bāla) have not abandoned such birth, death, etc.?

Answer: It is explained that consciousness of childish beings has not abandoned [birth, death, etc.]. Yet, because the primordial mind from the beginning does not have birth, aging, sickness and death together with their causes, [it] does not have to abandon them anew.

Questions:

- If ultimate sentient beings are not explained as the creators and experiencers of worldly pleasures and sufferings, then who will be explained as their creator and experiencer?

- When relative sentient beings experience worldly pleasures and sufferings, is the factor of clarity and cognition ( gsal rig gi cha)—the ultimate entity of those beings, not also present without difference in establishment and abiding ( $g r u b$ bde tha mi dad) with those subjects [i.e. consciousnesses of relative sentient beings]?

- Why is that very [phenomenon] which is experienced by relative sentient beings not experienced by their knowing and cognition (shes rig)? If it is experienced, then it will contradict [your] assertion of

102 Sublime Continuum, verse 51. The whole verse reads: "Because of having faults that are adventitious, // And positive qualities that are [in its] very nature, // Therefore, as it was before, so it is later, // [Its] reality unchangeable."

103 Emphasis mine. 
that knowing and cognition as the primordial mind. If it is not experienced, then would relative sentient beings, who [without cognition] turned into an [inanimate] matter, experience worldly pleasures and sufferings?

Answer: The answer to that, understood with difficulty (shes $d k a^{\prime} b a$ ), is as follows.

Followers of Mahāyāna do not explain as their tenets an existence of pleasures and sufferings apart from cognition (rnam rig, vijñapti), [that is] an appearance as worldly pleasures and sufferings to consciousness.

In that context, there are two [types of] cognition: the factor of outward-looking apprehended-aspect (kha phyir blta gzung rnam gyi cha) and the factor of inward-looking apprehender-aspect ( $k$ ha nang blta 'dzin rnam gyi cha). /121/ The acceptance of the first one as knowing and cognition [belongs] to Cittamātra tenets. This is like, [for example,] when explaining [the process of] seeing a form by the eye consciousness apprehending a form, [Cittamātra followers] accept that although there is no form, the seer [of form] is the mind itself.

Starting from the False Aspectarian Madhyamikas (rnam brdzun $d b u$ ma pa), [all Madhyamikas] have to explain the "non-duality of apprehended and apprehender"104 as [their own] tenets. Therefore, the apprehender is not accepted even as a functional thing (dngos po), ${ }^{105}$ how much less as consciousness.

The second one, the factor of inward-looking apprehender-aspect, is accepted as being the very entity and essence of all [types of] consciousness. But it is not accepted that [it] cognizes whatever appears as the object of consciousness (rnam shes kyi yul): [as Dharmakirti] said [in the third chapter of the Commentary on Valid Cognition]:

A mind is a conceptualization (rtog pa) of the object

With respect to which it apprehends sounds [as] meaning (sgra don 'dzin). ${ }^{106}$

With respect to its own entity, [a mind does] not [apprehend] sounds [as] meaning.

Therefore, with respect to that [entity], all [minds] are direct perceptions. ${ }^{107}$

104 I take gzugs 'dzin gnyis med in the text as a misspelling of gzung 'dzin gnyis med.

105 Notice a big difference between the apprehender/apprehended pair on the one hand and the apprehender-aspect/apprehended-aspect pair on the other. The apprehender here is the apprehended-aspect. (The apprehended then is external forms, etc., not the apprehended-aspect.)

106 I.e. apprehends sounds as suitable to be blended with the meaning they express. See the Appearance of Reasoning Defeating Bad Systems: Commentary on Difficult Points of the Extensive Treatise "Commentary of Valid Cognition" (rgyas pa'i bstan bcos tshad ma rnam 'grel gyi dka' 'grel rigs pa'i snang ba lugs ngan pham byed), vol. 19, 288, where Śākya Mchog ldan identifies sgra don 'zin as sgra don 'dres rung du 'dzin pa. (Hereafter, Appearance of Reasoning.)

107 Dharmakīrti, Commentary on Valid Cognition (Pramānavārttikakārikā, Tshad ma rnam 'grel gyi tshig le'ur byas pa), D4210, tshad ma, ce, 129b. Translation based on the Appearance of Reasoning, vol. 19, 288. At the end of the third line of this quote, yin is the misspelling of min, as is clear from the context, and also according to the Appearance of Reasoning, and the Commentary on Valid Cognition. 
Every phenomenon of a mistaken consciousness has the factor of the inward-looking primordial mind [related to it]. Nevertheless, it is impossible for the clarity-factor of the primordial mind (ye shes kyi gsal cha) to become the entity of consciousness, and it is also impossible for that [entity of consciousness] to become that [clarity-factor of the primordial mind]. Otherwise, it would follow that the primordial mind is an experiencer (myong ba po) of worldly pleasures and sufferings. [Also,] it would follow that those unreal ideations (yang dag pa ma yin pa'i kun tu rtog pa, abhütaparikalpa) that bear the name of consciousness, are the very basis of accomplishment of all stainless positive qualities.

Without that original primordial mind (gdod ma'i ye shes), the adventitious consciousness (blo bur gyi rnam shes) does not emerge as mistaken appearances. Nevertheless, the possibility of a common locus ( $g z h i m t-$ hun) of the two is not asserted. [Rather, they are] similar to clouds in the sky, rust ( $g . y a)$ on gold, and dirt (rnyog pa) in pure water.

Objection: If consciousness's own entity is not accepted as clarity and cognition (gsal rig), then it will not be cognizing objects because of [having absurdly turned into an inanimate] matter.

Answer: No [such] absurd consequence will apply [here]: in general, it is accepted that although consciousness is not established by valid cognition, because of a mistake it is only imputed as existent. [It is] not accepted even as existent-how much less a cognition-precisely because it is a relative truth. / 122/

Objection: In that case, since mistakes have no basis, mistaken appearances will be produced even without reliance on the primordial mind.

Answer: No. This is like, [for example,] if there is no cairn (mtho yor), concepts grasping [at it] as a human will not arise. Without the originally established primordial mind (gdod ma nas grub pa'i ye shes), mistaken appearances do not arise.

The factors of inward-looking apprehender-aspect (kha nang blta 'dzin rnam gyi cha) of mistaken appearances are definitely present as the original primordial mind. When followers of Secret Mantra [apply] skillful means of utilizing afflictions and concepts as the path,

- those present [inward-looking factors] initially [serve as] the basis of accomplishment of the Generation and Completion Stages;

- in the middle, [they] spontaneously become (lhun gyis grub) the very entity (ngo bo nyid) of those two [stages];

- [finally,] the outward-looking factors of the objects of abandonment become pacified by themselves (rang zhi) and purified by themselves (rang dag) like clouds dissolving into the sky. The outward-looking factors do not have to be abandoned by utilizing them as the path separately from those inward-looking [factors] that have become the very entity of the Generation and Completion Stages.

[The relationship between the inward-looking and outward-looking factors] is similar to the following example: without space (nam mkha'), 
appearances of pots, houses, etc., do not arise. Yet, space itself has not turned into the entity of pots, etc.

(2) The great translator [Rngog Blo Ldan Shes Rab] took the emptiness of mind with stains as [the meaning of] the essence. This is not good, because the identification of the essence has to be made in terms of the factor of positive qualities, while for emptiness alone (stong pa nyid rkyang $p a)$ that identification is not suitable.

Later Tibetans identified the essence as the naturally abiding lineage. That is also incorrect, because the lineage is identified in terms of having stains, while the essence has to be identified in terms of having no stains to eliminate.

Therefore, the suchness that is naturally pure of all faults, and [has] multiplicity of positive qualities of powers, etc., present in a natural, spontaneous way, is the actual essence identified as the very topic of this text [of the Sublime Continuum]. / 123/ The following textual passage [from the Sublime Continuum] together with its commentary [by Asanga] and sūtra [passages it relates to] are only literal:

Because suchness is indifferentiable, ...

Everybody has the buddha-essence. ${ }^{108}$

On the other hand, the following textual passage is only non-literal:

Because the body of the perfect buddha emanates, ...

All [beings] also have the buddha-essences. ${ }^{109}$

This is because

- [its] basis of intent is taught by:

And because of having lineage, ... ${ }^{110}$

- the purpose ${ }^{111}$ is taught by:

A discouraged mind, despising lowly sentient beings, ${ }^{112}$

[etc.]

- the damage to the explicit [teaching, ] is taught by:

There is no nirvāna apart from buddhahood. ${ }^{113}$

108 Sublime Continuum, in verse 28. For the full verse, see note 94 . Here and below, the lines of this verse are slightly modified.

109 Ibid.

110 Ibid.

111 Unless in this context, Saakya Mchog Ldan used them interchangeably, I take the text's dgongs pa (intent) to be a misspelling of dgos pa (purpose), one of the three elements of interpretive teachings. See also the discussion of verses 11-13 of the Essence of Sütras and Tantras.

112 Sublime Continuum, verse 84. The whole verse reads: "It was taught so that those who have five faults might abandon them. // [These five are] a discouraged mind, despising sentient beings as lowly, // Grasping at what is not real, deprecating real qualities, // And an excessive attachment to self." Also, see note 65.

113 Sublime Continuum, verse 84. The whole verse reads: "It is the dharma-body, it is the tathāgata, // It is the truth of āryas, the ultimate nirvāna. // Therefore, being indivisible from positive qualities like the sun and its rays, // There is no nirvāna apart from buddhahood." 
Question: Why does one [and the same] treatise explain [the essence] in two contradictory [ways]: as pervading and as not pervading sentient beings?

Answer: What is established [here is as follows]. Individual scriptures (gsung $r a b$ ) of the truly perfect Buddha teach the two ways: the essence pervading and not pervading sentient beings. The intent of those [teachings] was well explained by the foremost venerable Maitreya who divided the identification of the essence on [the basis of] the two truths [in his Sublime Continuum].

No author of such a definitive composition

Has [ever] appeared before in this Snowy Land [of Tibet].

With the exhortion by Dge 'Dun Dpal,

Let the harvest of virtue multiply!

Śubham!

Svasti!

The Sun Unseen Before: [Explanation of] the Definitive Meaning of the "Sublime Continuum"114 was sent to the spiritual friend Dge 'Dun Dpal. Although [he had actually] requested [me] to compose a commentary (țika) on this [Sublime Continuum] treatise, [I thought that there is] no problem of not having enough commentaries on this [treatise] that [already] emerged before. [On the other hand,] this [sun] unseen before that illuminates a billion [universes] with a single ray of light, is obtained [only] by the goods of your own virtuous qualities, Dge 'Dun Dpal! Therefore, [it] requires profound and extensive ways of determining [its meaning] by wisdom of listening and thinking.

\section{Śākya Mchog Ldan's writings that contain passages di- rectly addressing the buddha-essence in any significant extent}

(following the order of volumes of his collected works)

1. Enjoyment Ocean of Scriptural Statements and Reasoning Differentiating One's Own and Others' Tenets: Explanation of Difficult Points of the "Ornament of Clear Realizations" Treatise of Quintessential Instructions on the Perfection of Wisdom Together With Its Commentaries (Shes rab kyi pha rol tu phyin pa'i man ngag gi bstan bcos mngon par rtogs pa'i rgyan 'grel pa dang bcas pa'i dka' ba'i gnas rnams rnam par bshad pa rang gzhan gyi grub mtha' rnam par dbye ba lung rigs kyi rol mtsho). Vol. 1-2

2. Rain of Ambrosia: Extensive [Auto-]Commentary on the "Profound Thunder amidst the Clouds of the Ocean of Definitive Meaning" (Nges don rgya mtsho sprin gyi 'brug sgra zab mo'i rgyas 'grel bdud rtsi'i char 'bebs). Vol. 2

114 The wording here is slightly different from the one in the title above. 
3. Ocean of the Meaning of Scriptural Statements: Extensive Explanation of the Body and Branches of the Perfection of Wisdom Sütras and the "Ornament of Clear Realizations" Together with Commentaries (Shes rab kyi pha rol tu phyin pa'i mdo dang mngon par rtogs pa'i rgyan 'grel dang bcas pa'i lus dang yan lag rgyas par bshad pa lung don rgya mtsho). Vol. 3

4. Essence of the Ocean of Scriptural Doctrines: Condensation of Desiderata of General Meaning of the "Ornament of Clear Realizations" with Its Commentaries (Mngon par rtogs pa'i rgyan 'grel pa dang bcas pa'i spyi'i don nyer mkho bsdus pa lung chos rgya mtsho'i snying po). Vol. 3

5. Golden Spoon: A Resolved Abundant Discourse on the "Clear Differentiation of the Three Codes" Treatise (Sdom gsum gyi rab tu dbye ba'i bstan bcos kyi 'bel gtam rnam par nges pa legs bshad gser gyi thur ma). Vol. 6-7

6. Ascertainment of the Dharma Sphere: Explanation of [Nāgārjuna's] Treatise "Praise of the Dharma-Sphere" (Chos kyi dbyings su bstod pa zhes bya ba'i bstan bcos kyi rnam par bshad pa chos kyi dbyings rnam par nges pa). Vol. 7

7. Sevenfold Treasury of Gems: Explanation of the Glorious "Secret Assembly" (Dpal gsang ba 'dus pa'i rnam bshad rin po che'i gter mdzod bdun pa). Vol. 7

8. Thorough Establishment of the Glorious Original Buddha (Dpal dang po'i sangs rgyas rab tu grub pa). Vol. 8

9. Thorough Clarification of the Definitive Meaning of the Five Doctrines of Maitreya (Byams chos lnga'i nges don rab tu gsal ba zhes bya ba'i bstan bcos). Vol. 11

10. Opening the Doors of the Chest of Gems: Treatise Elucidating the Stages of the Path of the Five Doctrines of Maitreya (Byams chos Inga'i lam gyi rim pa gsal bar byed pa'i bstan bcos rin chen sgrom gyi sgo 'byed. Vol. 11

11. The Sun Unseen Before: the Definitive Meaning of the "Sublime Continuum" Treatise (Rgyud bla ma'i bstan bcos kyi nges don sngon med nyi ma). Vol. 13

12. Essence of Sūtras and Tantras: Explanation of the Buddha-essence (Sangs rgyas kyi snying po'i rnam bshad mdo rgyud snying po). Vol. 13

13. Treatise Ascertaining the Ways of Positing the Two Truths (Bden pa gnyis kyi bzhag tshul rnam par nges pa'i bstan bcos). Vol. 13

14. Answers to Objections to the "Establishment of the Original Buddha" Text (Dang po'i sangs rgyas grub pa'i gzhung gi brgal lan). Vol. 13

15. Opening Hundred Doors of the Treasury of Ascertainment of the DharmaSphere (Chos kyi dbyings rnam par nges pa'i gter sgo brgya 'byed)

16. Ocean of Scriptural Statements and Reasoning: Treasury of Ascertainment of the Mahāyāna Madhyamaka (Theg pa chen po dbu ma rnam par nges pa'i bang mdzod lung dang rigs pa'i rgya mtsho). Vol. 14-15

17. Cleansing the Heart Darkness with the Appearance of the Sun of Definitive Meaning: Description of Realizations of the Glorious Being of Great Nature Honorable Ārya Nāgārjuna (Dpal bdag nyid chen po 'phags pa klu sgrub zhabs kyi rtogs pa brjod pa nges don nyin mor byed pa'i snang bas snying gi mun pa sangs byed). Vol. 16

18. Taking Away the Heart Torments with the Garland of the White Moonrays of Definitive Meaning: Description of Realizations of Honorable ārya Asan_ga ('Phags pa thogs med zhabs kyi rtogs pa brjod pa nges don zla zer dkar po'i phreng bas snying gi gdung ba 'phrog byed). Vol. 16 
19. Answers to the Three Universally Known Questions from the "One Hundred and Eight Questions on the 'Clear Differentiation of the Three Codes'" (Sdom pa gsum gyi rab dbye'i dri ba brgya dang brgyad las kun la grags che ba'i dri ba gsum gyi lan gdabs pa). Vol. 17

20. Precious Harbor of Definitive Meaning (Nges don rin po che'i 'jug ngogs). Vol. 17

21. Resolved Thorough Clarification or Thorough Clarification of the Definitive Meaning: An Abundant Discourse Eliminating Qualms Issuing from the "Golden Spoon" (gser gyi thur ma las brtsams pa'i dogs gcod kyi 'bel gtam rab gsal rnam nges sam / nges don rab gsal). Vol. 17

22. Answers to the Questions of Blo Mchog (Blo mchog pa'i dri lan). Vol. 17

23. Meaningful to Behold: Answers to the Questions of Spiritual Friend Mus Pa Rab 'Byams Pa (Bshes gnyen mus pa rab 'byams pa'i dri lan mthong ba don ldan). Vol. 23

24. Seventeen Wondrous Answers to The Questions of the Whole Monastic Community of Gzi Bsam 'Grub Gling (Gzi bsam 'grub gling pa'i dge 'dun spyi'i dris lan ya mtshan bcu bdun pa). Vol. 23

\section{References}

Sūtras and tantras

Hevajra Tantra (Hevajratantrarājanāma, Kye'i rdo rje zhes bya ba rgyud kyi rgyal po), D417, rgyud, nga, 1b-30a.

Descent into Lañkā Sūtra (Āryalañkāvatāramahāyānasūtra, 'Phags pa lang kar gshegs pa'i theg pa chen po'i mdo), D 107, mdo sde, ca, 56a-191b.

Great Nirvāna Sūtra (Āryamahāparinirvānanāmamahāyānasūtra, 'Phags pa yongs su mya ngan las 'das pa chen po'i mdo), D119, mdo sde, nya, 1b-ta 339a; D120, mdo sde, tha 1b-151a; D121, mdo sde, tha, 151a-152b.

Purity from Karmic Obscurations Sūtra ('Phags pa las kyi sgrib pa rnam par dag pa zhes bya ba theg pa chen po'i mdo, Āryakarmāvaraṇaviśuddhināmamahāyānasūtra), D218, mdo sde, tsha, 284a-297b.

Secret Assembly Tantra (Sarvatathāgatakāyavākcittarahasyaguhyasamājanāmamahākal parāja, De bzhin gshegs pa thams cad kyi sku gsung thugs kyi gsang chen gsang ba 'dus pa zhes bya ba brtag pa' i rgyal po chen po), D443, rgyud, ca, 90a-157b.

Sūtra of the Ornament of Appearances of the Primordial Mind (Āryasarvabuddhaviśayāvatārajñānālokālaṃkāranāmamahāyānasātra, 'Phags pa sangs rgyas thams cad kyi yul la 'jug pa'i ye shes snang ba'i rgyan ces bya ba theg pa chen po'i mdo), D100, mdo sde, ga, 276a-305a.

Wheel of Time Tantra (Paramādibuddhoddhritaśrīkālacakranāmatantrarājā, Mchog gi dang po' i sangs rgyas las phyung ba rgyud kyi rgyal po dpal dus kyi 'khor lo zhes bya ba), D0362, rgyud, ka 22b-128b.

Works by Indian and Tibetan authors

Asanga. Summary of Higher Knowledge (Abhidharmasamuccaya, Chos mngon pa kun las btus pa), D4053, sems tsam, li, 1a-117a.

Asañga. Summary of Mahāyāna (Mahāyānasaṃgraha, Theg pa chen po bsdus pa), D4048, sems tsam, ri, 1a-43a.

Asañga. Explanation of [Maitreya's] "Sublime Continuum of Mahāyāna" (Mahāyānottaratantraśāstravyākhyā, Theg pa chen po'i rgyud bla ma'i bstan bcos kyi rnam par bshad pa). D4025, sems tsam, phi, 74b-129a. 
Dharmakīrti. Commentary on Valid Cognition (Pramānavārttikakārikā, Tshad ma rnam 'grel gyi tshig le'ur byas pa). D4210, tshad ma, ce, 94b-151a.

Kun dga' grol mchog (1975). Detailed Analysis of the Biography of the Great Pandita Śákya Mchog Ldan (Paṇi ta chen po Śäkya Mchog Ldan gyi rnam par thar pa zhib mo rnam 'byed pa). Collected Works, Vol. 16. Thimphu, Bhutan: Kunzang Tobgyey.

Maitreya, Ornament of Mahāyāna Sūtras (Mahāyānasūtrālaṃkāra, Theg pa chen po mdo sde'i rgyan), D4020, sems tsam, phi, 1a-39a.

Maitreya. (1966) Sublime Continuum of Mahāyāna (Mahāyānottaratantraśāstra, Theg pa chen po rgyud bla ma). D4024, sems tsam, phi, 54b-73a. English translation in Takasaki, Jikido. A Study on the Ratnagotravibhāga. Rome: Istituto Italiano per il Medio ed Estremo Oriente.

Nāgārjuna. Praise of the Dharma-Sphere (Dharmadhātustotra, Chos kyi dbyings su bstod pa). D1118, ka, 63b-67b.

Pundarīka. Stainless Light Commentary (Vimalaprabhā, Dri ma med pa'i 'od; the full title: Vimalaprabhānāmamūlatantrānusāriṇīvādaśasāhasrikālaghukālacakratantrar ājațīkā, Bsdus pa'i rgyud kyi rgyal po dus kyi 'khor lo'i 'grel bshad rtsa ba'i rgyud kyi rjes su 'jug pa stong phrag bcu pa bcu gnyis pa dri ma med pa'i 'od ces bya ba). D1347, rgyud 'grel, tha, 107b-da, 297a.

Śakya Mchog Ldan. (1975). Answers to Objections to the "Establishment of the Original Buddha" Text (Dang po'i sangs rgyas grub pa'i gzhung gi brgal lan). Collected Works, Vol. 13. Thimphu, Bhutan: Kunzang Tobgyey.

Śākya Mchog Ldan. (1975). Answers to the Questions of Blo Mchog (Blo mchog pa'i dri lan). Collected Works, Vol. 17. Thimphu, Bhutan: Kunzang Tobgyey.

Śākya Mchog Ldan. (1975). Appearance of Reasoning Defeating Bad Systems: Commentary on Difficult Points of the Extensive Treatise "Commentary of Valid Cognition" (Rgyas pa'i bstan bcos tshad ma rnam 'grel gyi dka' 'grel rigs pa'i snang ba lugs ngan pham byed). Collected Works, Vol. 19. Thimphu, Bhutan: Kunzang Tobgyey

Śākya Mchog Ldan. (1975). Cleansing the Heart Darkness with the Appearance of the Sun of Definitive Meaning: Description of Realizations of the Glorious Being of Great Nature Honorable Ārya Nāgärjuna (Dpal bdag nyid chen po 'phags pa klu sgrub zhabs kyi rtogs pa brjod pa nges don nyin mor byed pa'i snang bas snying gi mun pa sangs byed). Collected Works, Vol. 16. Thimphu, Bhutan: Kunzang Tobgyey.

Śākya Mchog Ldan. (1975). Drumming Sounds of Melodious Voice of Brahma: Refutation of Mistakes About Meditative Stages of the Great Middle and Explanation of the Tenets and Topics of the Views of Consequentialists and Autonomists (Dbu ma chen po'i sgom rim la' khrul pa spong shing thal rang gi grub pa'i mtha' dang lta ba'i gnas rnam par bshad pa tshangs pa'i dbyangs kyi rnga sgra). Collected Works, Vol. 4. Thimphu, Bhutan: Kunzang Tobgyey.

Śākya Mchog Ldan. Enjoyment Ocean of Scriptural Statements and Reasoning Differentiating One's Own and Others' Tenets: Explanation of Difficult Points of the "Ornament of Clear Realizations" Treatise of the Quintessential Instructions on the Perfection of Wisdom Together With Its Commentaries (Shes rab kyi pha rol tu phyin pa'i man ngag gi bstan bcos mngon par rtogs pa'i rgyan 'grel pa dang bcas pa'i dka' ba'i gnas rnams rnam par bshad pa rang gzhan gyi grub mtha' rnam par dbye ba lung rigs kyi rol mtsho), Vol. 2

Śākya Mchog Ldan. (1975). Essence of Sūtras and Tantras: Explanation of the Buddhaessence (Sangs rgyas kyi snying po'i rnam bshad mdo rgyud snying po). Collected Works, Vol. 13. Thimphu, Bhutan: Kunzang Tobgyey.

Śākya Mchog Ldan. (1975). Essence of the Ocean of Scriptural Doctrines: Condensation of Desiderata of General Meaning of the "Ornament of Clear Realizations" with Its Commentaries (Mngon par rtogs pa'i rgyan 'grel pa dang bcas pa'i spyi'i don nyer mkho bsdus pa lung chos rgya mtsho'i snying po). Collected Works, Vol. 3. Thimphu, Bhutan: Kunzang Tobgyey. 
Śākya Mchog Ldan. (1975). Golden Spoon: A Resolved Abundant Discourse on the "Clear Differentiation of the Three Codes" Treatise (Sdom gsum gyi rab tu dbye ba'i bstan bcos kyi 'bel gtam rnam par nges pa legs bshad gser gyi thur ma). Collected Works, Vol. 6-7. Thimphu, Bhutan: Kunzang Tobgyey.

Śākya Mchog Ldan. (1975). Good Questions about the "Clear Differentiation of the Three Codes" (Sdom gsum rab dbye la dri ba legs pa). Collected Works, Vol. 17. Thimphu, Bhutan: Kunzang Tobgyey.

Sákya Mchog Ldan. (1975). Meaningful to Behold: Answers to the Questions of Spiritual Friend Mus Pa Rab 'Byams Pa (Bshes gnyen mus pa rab 'byams pa'i dri lan mthong ba don ldan). Collected Works, Vol. 23. Thimphu, Bhutan: Kunzang Tobgyey.

Śākya Mchog Ldan. (1975). Ocean of Scriptural Statements and Reasoning: Treasury of Ascertainment of the Mahāyāna Madhyamaka (Theg pa chen po dbu ma rnam par nges pa'i bang mdzod lung dang rigs pa'i rgya mtsho). Collected Works, vols. 14-15. Thimphu, Bhutan: Kunzang Tobgyey.

Śākya Mchog Ldan. (1975). Ocean of the Meaning of Scriptural Statements: Extensive Explanation of the Body and Branches of the Perfection of Wisdom Sütras and the "Ornament of Clear Realizations" Together with Commentaries (Shes rab kyi pha rol tu phyin pa'i mdo dang mngon par rtogs pa'i rgyan 'grel dang bcas pa'i lus dang yan lag rgyas par bshad pa lung don rgya mtsho). Collected Works, Vol. 3. Thimphu, Bhutan: Kunzang Tobgyey.

Śăkya Mchog Ldan. (1975). Opening the Doors of the Chest of Gems: Treatise Elucidating the Stages of the Path of the Five Doctrines of Maitreya (Byams chos Inga'i lam gyi rim pa gsal bar byed pa'i bstan bcos rin chen sgrom gyi sgo 'byed). Collected Works, Vol. 11. Thimphu, Bhutan: Kunzang Tobgyey.

Śākya Mchog Ldan. (1975). Rain of Ambrosia: Extensive [Auto-] Commentary on the "Profound Thunder amidst the Clouds of the Ocean of Definitive Meaning" (Nges don rgya mtsho sprin gyi 'brug sgra zab mo'i rgyas 'grel bdud rtsi'i char 'bebs). Collected Works, Vol. 2. Thimphu, Bhutan: Kunzang Tobgyey.

Śākya Mchog Ldan. (1975). Resolved Thorough Clarification or Thorough Clarification of the Definitive Meaning: Abundant Discourse Eliminating Qualms Issuing from the "Golden Spoon" (Gser gyi thur ma las brtsams pa'i dogs gcod kyi 'bel gtam rab gsal rnam nges sam / nges don rab gsal). Collected Works, Vol. 17. Thimphu, Bhutan: Kunzang Tobgyey.

Śākya Mchog Ldan. (1975). Seventeen Wondrous Answers to The Questions of the Whole Monastic Community of Gzi Bsam 'Grub Gling (Gzi bsam 'grub gling pa'i dge 'dun spyi'i dris lan ya mtshan bcu bdun pa). Collected Works, Vol. 23. Thimphu, Bhutan: Kunzang Tobgyey.

Śākya Mchog Ldan. (1975). The Sun Unseen Before: the Definitive Meaning of the "Sublime Continuum" Treatise (Rgyud bla ma'i bstan bcos kyi nges don sngon med nyi $m a$ ). Collected Works, Vol. 13. Thimphu, Bhutan: Kunzang Tobgyey.

Sa skya Pandita Kun dga' rgyal mtshan. (2002). Clear Differentiation of the Three Codes (Sdom pa gsum gyi rab tu dbye ba). Sa skya bka' 'bum, Vol. 12 (na), 1a-48b. English translation by Rhoton, Jared Douglas. A Clear Differentiation of the Three Codes: Essential Distinctions among the Individual Liberation, Mahāyāna, and Tantric Systems. Albany, New York: State University of New York Press.

Vajragarbha. Extensive Commentary on the "Condensed Meaning of the Hevajra Tantra" (Hevajrapinḍārthațiikā, Kye'i rdo rje bsdus pa'i don gyi rgya cher 'grel pa, D1180, ka, 1-126a).

Vajrapāni. Meaning Commentary on the Cakrasaṃvara Tantra (Lakșābhidhanāduddhrtalaghutantrapindārthavivarana, Mngon par brjod pa 'bum pa las phyung ba nyung ngu'i rgyud kyi bsdus pa'i don rnam par bshad pa, D1402, ba, 78b-141a). 